Article

\title{
Dust-Associated Airborne Microbes Affect Primary and Bacterial Production Rates, and Eukaryotes Diversity, in the Northern Red Sea: A Mesocosm Approach
}

\author{
Esra Mescioglu 1,*(D), Eyal Rahav ${ }^{2}$, Miguel J. Frada ${ }^{3,4}$, Sahar Rosenfeld ${ }^{2}$, Ofrat Raveh ${ }^{2}$, \\ Yuri Galletti ${ }^{5}$, Chiara Santinelli ${ }^{5}$, Barak Herut ${ }^{2}$ (D) and Adina Paytan 6 (D) \\ 1 Earth and Planetary Sciences, University of California, Santa Cruz, CA 95060, USA \\ 2 Israel Oceanographic and Limnological Research, National Institute of Oceanography, 3108000 Haifa, Israel \\ 3 The Interuniversity Institute for Marine Sciences of Eilat, POB 469, 88103 Eilat, Israel \\ 4 Department of Ecology, Evolution and Behavior-Alexander Silberman Institute of Life Sciences, \\ Hebrew University of Jerusalem, 91904 Jerusalem, Israel \\ 5 Institute of Biophysics, CNR, 56124 Pisa, Italy \\ 6 Institute of Marine Science, University of California, Santa Cruz, CA 95060, USA \\ * Correspondence: Emesciog@ucsc.edu
}

Received: 17 June 2019; Accepted: 26 June 2019; Published: 28 June 2019

check for updates

\begin{abstract}
The northern Red Sea (NRS) is a low-nutrient, low-chlorophyll (LNLC) ecosystem with high rates of atmospheric deposition due to its proximity to arid regions. Impacts of atmospheric deposition on LNLC ecosystems have been attributed to the chemical constituents of dust, while overlooking bioaerosols. Understanding how these vast areas of the ocean will respond to future climate and anthropogenic change hinges on the response of microbial communities to these changes. We tested the impacts of bioaerosols on the surface water microbial diversity and the primary and bacterial production rates in the NRS, a system representative of other LNLC oceanic regions, using a mesocosm bioassay experiment. By treating NRS surface seawater with dust, which contained nutrients, metals, and viable organisms, and "UV-treated dust" (which contained only nutrients and metals), we were able to assess the impacts of bioaerosols on local natural microbial populations. Following amendments (20 and $44 \mathrm{~h}$ ) the incubations treated with "live dust" showed different responses than those with UV-treated dust. After $44 \mathrm{~h}$, primary production was suppressed (as much as $50 \%$ ), and bacterial production increased (as much as 55\%) in the live dust treatments relative to incubations amended with UV-treated dust or the control. The diversity of eukaryotes was lower in treatments with airborne microbes. These results suggest that the airborne microorganisms and viruses alter the surface microbial ecology of the NRS. These results may have implications for the carbon cycle in LNLC ecosystems, which are expanding and are especially important since dust storms are predicted to increase in the future due to desertification and expansion of arid regions.
\end{abstract}

Keywords: airborne microbes; bioaerosols; northern Red Sea; low-chlorophyll low-nutrient; primary production; bacterial production

\section{Introduction}

Aerosols impact marine ecosystems by delivering macro- and micronutrients to surface seawater upon deposition [1-3]. These nutrients typically induce an increase in phytoplankton abundance and bacterial biomass and activity [4-7]. Atmospheric deposition also supplies a diverse array of microbes to marine ecosystems [8-10], of which up to $25 \%$ remain viable [11]. Upon deposition, 
airborne microorganisms affect phytoplankton/bacterial populations in surface seawater [7,12-14], and contribute to bacterial production [13] and $\mathrm{N}_{2}$ fixation [7,14], impacting both the carbon (C) and the nitrogen $(\mathrm{N})$ cycles.

The impact of airborne microbes may be particularly important in low-nutrient low-chlorophyll (LNLC) regions, which make up $60 \%$ of the global oceans [15], particularly where or when aerosol deposition rates are high. The Gulf of Aqaba (GOA) in the northern Red Sea (NRS) is a LNLC region with high atmospheric deposition due to its proximity to the Arabian, Sahel, Negev, and Sahara deserts. This proximity leads to high annual rates of dust deposition $\left(50-500 \mathrm{~g} \mathrm{~m}^{-2}\right)$ in the NRS, with average dust loads reaching $\sim 40 \mu \mathrm{g} \mathrm{m}^{-3}$ and $\sim 700 \mu \mathrm{g} \mathrm{m}^{-3}$ during normal non-storm conditions and single dust storm events, respectively [16-18]. Previous studies showed that dust deposition in the NRS surface waters may alter chlorophyll $a$ concentration, especially during the stratified most oligotrophic conditions in summer [17].

Thus far, observed changes in phytoplankton abundance (Prochlorococcus, Synechococcus, and picoeukaryotes) following aerosol deposition events or in simulated deposition experiments, have been solely attributed to the chemical constituents of aerosols (i.e., nutrients) [19], while biotic constituents have been typically ignored [7]. This has also been the case for the NRS [20], despite reports that diverse arrays of microorganisms are present in aerosols in neighboring systems [13,21,22], including the NRS [23].

Currently, the impact of airborne microbes on native phytoplankton and bacterial populations and putative antagonistic or synergistic relationships that may occur are still poorly assessed. In this study, we investigated the role of dust-associated airborne microbes on primary and bacterial production using the NRS as a model ecosystem. To this end, we conducted mesocosm experiments where "live dust" (containing potentially viable airborne microbes and nutrients) or "UV-treated dust" (contributing only leached chemical constituents) were added to surface seawater collected from the NRS. Microbial abundances and both primary and bacterial production were measured daily over $72 \mathrm{~h}$. Metagenomics was used to assess how the surface water microbial community changed after the dust amendments and differences between live and "UV-treated" dust additions assessed.

\section{Methods}

\subsection{Dust Collection}

Dust was collected at the NRS $\left(29^{\circ} 28^{\prime} \mathrm{N}, 34^{\circ} 55^{\prime} \mathrm{E}\right)$ on 18 May 2017, during a large storm event that originated from the Sahara Desert [7]. Dust particles were collected on pre-cleaned glass plates and kept frozen (which may have impacted viability of some of the organisms) until the experiment in July 2017. Prior to the experiment a subsample of the dust was placed under UV light for $48 \mathrm{~h}$ to kill the microorganisms associated with it (hereafter referred to as "UV-treated dust"). It has been shown that $>95 \%$ of airborne microbes are inactivated by this UV treatment [7]. The remaining dust samples were left as is (hereafter referred to as "live dust"). Thus, live dust contributed nutrients, trace metals, and airborne microorganisms to the microcosms, whereas the UV-treated dust contributed only nutrients and trace metals.

\subsection{Experimental Setup}

In order to assess the specific contribution/impact of viable airborne microorganisms following dust deposition events in the NRS, surface seawater (from $~ 10 \mathrm{~m}$ depth) from the NRS was homogeneously distributed into nine polycarbonate mesocosm bags (each $300 \mathrm{~L}$ ) on 9 July 2017. The mesocosms were submerged in a shaded pool with circulating seawater to maintain ambient temperatures $\left(25-28{ }^{\circ} \mathrm{C}\right)$ and low light intensities (80-100 $\mu \mathrm{mol}$ quanta $\mathrm{m}^{-2} \mathrm{~s}^{-1}$ during midday, LI-COR PAR sensor) (Figure 1). The mesocosms were amended with the following treatments, in triplicate: (1) seawater with the addition of $0.8 \mathrm{mg} \mathrm{L}^{-1}$ of dust (live dust), (2) seawater with the addition of $0.8 \mathrm{mg} \mathrm{L}^{-1}$ of UV-treated dust, and finally (3) unamended seawater as a control (seawater with no dust added to simulate 
normal non-dust storm conditions). The amount of dust added $\left(0.8 \mathrm{mg} \mathrm{L}^{-1}\right)$ was within the range of natural atmospheric deposition to the upper mixed layer of the NRS $(\sim 15 \mathrm{~m})$ during intense dust storm events $[17,24,25]$.The bags were mixed and subsampled before amendments were added at $6,24,44$, and $72 \mathrm{~h}$ post dust additions as described below. We note that what we refer to as dust includes not only mineral dust but also other aerosol constituents that were deposited along with the mineral dust during the storm.

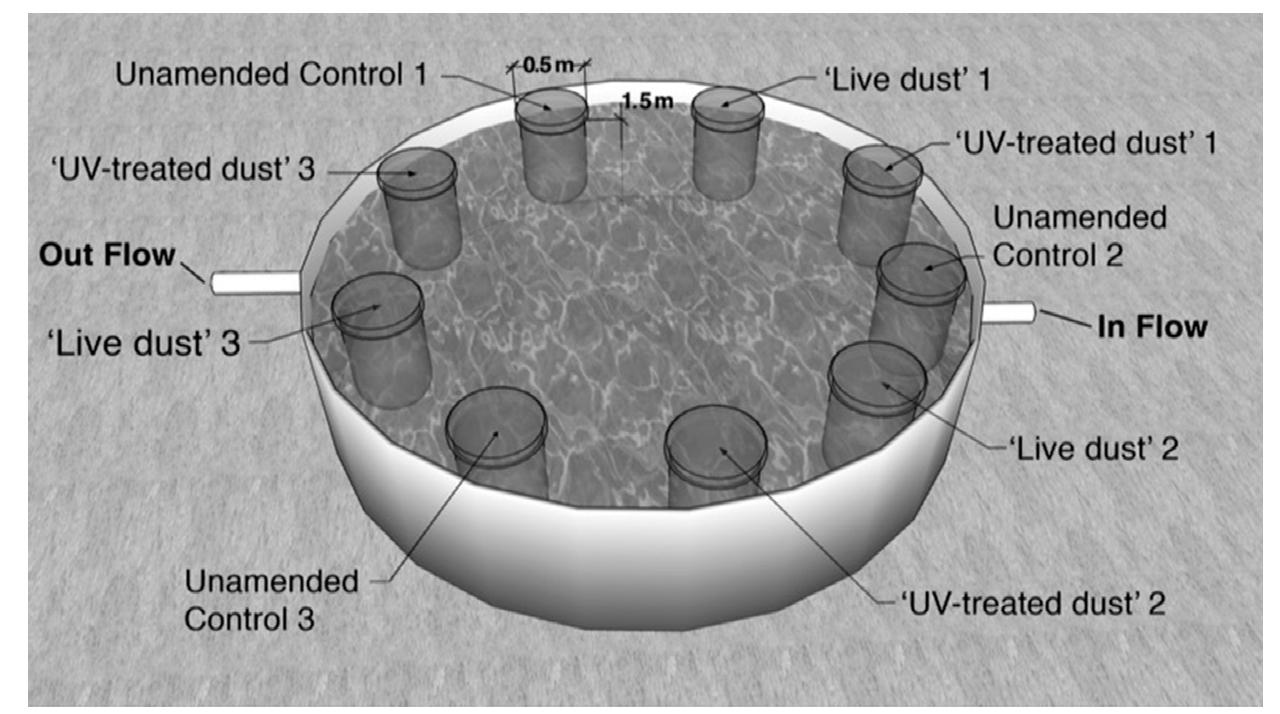

Figure 1. An illustration of the experimental mesocosm used in this study. Treatments included unamended controls, live dust and UV-treated dust run in triplicate $300 \mathrm{~L}$ transparent bags.

\subsection{Bacterial Production (BP) and Primary Production (PP)}

To quantify the impacts of airborne microbes on heterotrophic production, BP was measured using the (4,5-3H)-leucine incorporation method [26]. Briefly, seawater samples collected daily from the mesocosms $(1.7 \mathrm{~mL})$ were amended with $10 \mathrm{nmol}$ of leucine $\mathrm{L}^{-1}$ (Perkin Elmer, specific activity $156 \mathrm{Ci} \mathrm{mmol}^{-1}$ ) and incubated for $4-6 \mathrm{~h}$ in the dark. Incubations were stopped by the addition of $100 \mu \mathrm{L}$ of cold $100 \%$ trichloroacetic acid (TCA). Control samples containing seawater, radioisotope, and TCA added immediately upon collection were also run daily. At the lab, the samples were microcentrifuged twice with TCA $5 \%$ and $1 \mathrm{~mL}$ of scintillation cocktail (Ultima-Gold) was added to each vial. Disintegrations per minute (DPM) were measured using a TRI-CARB 2100 TR (Packard) liquid counter. A conversion factor of $1.5 \mathrm{~kg} \mathrm{C} \mathrm{mol}^{-1}$ per mole leucine was used [27].

To assess the impacts of airborne microbes on autotrophic production, the PP was measured following the ${ }^{14} \mathrm{C}$ incorporation method [28]. Briefly, water samples were analyzed in triplicate with dark and zero time controls. The samples $(50 \mathrm{~mL})$ were collected at 8:00 a.m. into transparent polycarbonate bottles (Nalgene) and amended with $5 \mu \mathrm{Ci}$ of $\mathrm{NaH}^{14} \mathrm{CO}_{3}$ (Perkin Elmer). The bottles were incubated for $4-6 \mathrm{~h}$ in the same pool where the mesocosms were placed. The incubations were terminated by filtering the spiked seawater onto $\mathrm{GF} / \mathrm{F}$ filters under low pressure $(<50 \mathrm{mmHg})$. Excess ${ }^{14} \mathrm{C}$-bicarbonate was removed from the filters by acidification with $\mathrm{HCl}(32 \%)$ overnight. After adding $5 \mathrm{~mL}$ of scintillation cocktail (Ultima-Gold) to each vial, the radioactivity was measured using a TRI-CARB 2100 TR (Packard) liquid counter.

\subsection{Chlorophyll-a (Chl-a)}

To measure Chl- $a$, a proxy for total phytoplankton biomass, subsamples of seawater $(500 \mathrm{~mL})$ collected from the different mesocosms were passed through a Whatman GF/F filter, and $90 \%$ acetone solution was used for overnight extraction. The Chl- $a$ concentrations were quantified using the 
non-acidification method [29], using a Trigoly fluorimeter equipped with $436 \mathrm{~nm}$ excitation and $680 \mathrm{~nm}$ emission filters.

\subsection{Picophytoplankton and Heterotrophic Bacterial Abundance}

To quantify the abundance of picophytoplankton and heterotrophic bacteria, seawater subsamples $(1.7 \mathrm{~mL})$ were collected from the different mesocosm bags, fixed with $50 \%$ glutaraldehyde $(0.15 \%$ final concentration, Sigma G7651), incubated for $10 \mathrm{~min}$ at room temperature, snap frozen in liquid nitrogen, and stored in $-80^{\circ} \mathrm{C}$ until analyses within a few weeks. Cell counts were performed by flow cytometry (Attune, Applied Biosystems) equipped with a syringe-based fluidic system and $488 \mathrm{~nm}$ and $405 \mathrm{~nm}$ lasers. Cyanobacteria (Synechococcus and Prochlorococcus) and picoeukaryotes were detected based on the orange fluorescence of phycoerythrin $(585 \mathrm{~nm})$ and the red fluorescence of Chl- $a(630 \mathrm{~nm})$, side scattered and forward scattered at a flow rate of $100 \mu \mathrm{min}^{-1}$. Heterotrophic bacterial cells were first stained with a SYTO9 solution for $10 \mathrm{~min}$ in the dark and then run at a low flow rate of $25 \mu \mathrm{L} \mathrm{min}{ }^{-1}$ using a discrimination threshold of green fluorescence $(520 \mathrm{~nm})$. One $\mu \mathrm{m}$ beads (Polysciences) were used as internal reference.

\section{6. $\beta$-Glucosidase ( $\beta$-Glu), Aminopeptidase (AMA), and Alkaline Phosphatase (APA) Activity}

To determine the rate of polysaccharide degradation by bacteria, $\beta$-Glu activity was determined by the 4-methylumbelliferyl- $\beta$-D-glucopyranoside (Sigma M3633) method [30], and AMA was determined by the L-Leu-7-amido-4-methyl-coumarin method. Substrate was added in triplicate to $1 \mathrm{~mL}$ water samples (final concentration of $50 \mu \mathrm{M}$ ) and incubated in the dark at an ambient temperature for $24 \mathrm{~h}$. To assess the rate of scavenging of organic matter due to phosphate limitation, the APA was determined by the 4-methylumbeliferyl phosphate (MUF-P: Sigma M8168) method [31]. Substrate was added in triplicate to $1 \mathrm{~mL}$ water samples (final concentration of $50 \mu \mathrm{M}$ ) and incubated in the dark at an ambient temperature for $24 \mathrm{~h}$. The increase in fluorescence of 4-methylumbelliferone (MUF) was measured at $365 \mathrm{~nm}$ excitation, $455 \mathrm{~nm}$ emissions (GloMax®-Multi Detection System E9032) and calibrated against a MUF standard (Sigma M1508).

\subsection{DNA Extraction, Library Preperation, and Sequencing}

To assess the diversity of microorganisms, seawater $(1 \mathrm{~L})$ from each mesocosm was filtered onto $0.2 \mu \mathrm{m}$ polycarbonate filters. Total DNA was extracted from the filters using the phenol chloroform method [32]. Total DNA was also extracted from the aerosols collected using the same method. Polymerase chain reaction (PCR) using primers 515 (forward) and 806 (reverse) for 16S rRNA and primers EUK7F (forward) and EUK570R (reverse) for 18S rRNA, with barcodes on the forward primer, were carried out using the HotStarTaq Plus Master Mix Kit (Qiagen, Valencia, CA, USA). The samples were pooled together in equal proportions (based on their MW and DNA concentrations), purified using calibrated Ampure XP beads, and used to prepare libraries using a Nextera DNA Sample Preparation Kit (IllFumina). Libraries were loaded to a 600 Cycles v3 Reagent cartridge (Illumina) and sequenced by illumina MiSeq.

\subsection{Bioinformatics}

Samples were processed using the open-source Quantitative Insights into Microbial Ecology 2 (QIIME 2) pipeline [33]. Sequences were demultiplexed and barcodes were trimmed. Data were denoised using DADA2 [34], sequences were clustered into amplicon sequence variants (ASVs) which can be thought of as 100\% operational taxonomic units (OTUs). Taxonomic classifier was trained [35] using Greengenes [36] for $16 \mathrm{~S}$ and Silva [37] for 18S. Taxonomies were assigned using the naive Bayes method [38]. 


\subsection{Statistical Analysis}

The data in figures and tables are means and standard deviations $(n=3)$. Differences between treatments were tested using analysis of variance (ANOVA) and Tukey's post-hoc testing, and a $p$-value of 0.05 was used to determine significance unless noted otherwise. All tests were performed using R.

\section{Results}

The initial properties of the NRS surface waters used in the experiment (i.e., control mesocosms) are as shown in Rahav et al. [7]. Briefly, the surface water of the NRS exhibited oligotrophic characteristics with low micro- and macronutrients levels that were representative of summer conditions in the NRS: $\mathrm{NO}_{3}+\mathrm{NO}_{2}(140 \pm 13 \mathrm{nM}), \mathrm{PO}_{4}(8 \pm 1 \mathrm{nM}), \mathrm{DOC}(74 \pm 1 \mu \mathrm{M}), \mathrm{Fe}(8.5 \pm 1.8 \mathrm{nM}), \mathrm{Zn}(8.7 \pm 2.1 \mathrm{nM})$ and $\mathrm{Cu}(1.4 \pm 0.9 \mathrm{nM})[39,40]$. Additionally, bacterial abundance $\left(3.5 \times 10^{5} \pm 15 \times 10^{4} \mathrm{cell} / \mathrm{mL}\right)$, bacterial production $\left(1.41 \pm 0.08 \mu \mathrm{g} \mathrm{C} \mathrm{L}^{-1} \mathrm{~h}^{-1}\right)$, primary production $\left(0.60 \pm 0.01 \mu \mathrm{g} \mathrm{C} \mathrm{L}^{-1} \mathrm{~h}^{-1}\right)$, B-Gl $\left(1.42 \pm 0.07 \mathrm{nM} \mathrm{L}^{-1} \mathrm{~h}^{-1}\right)$, APA $\left(5.58 \pm 0.17 \mathrm{nM} \mathrm{L}^{-1} \mathrm{~h}^{-1}\right)$, AMA $\left(2.60 \pm 0.09 \mathrm{nM} \mathrm{L}^{-1} \mathrm{~h}^{-1}\right)$, Chl- $a$ $(0.28 \pm 0.01 \mu \mathrm{g} / \mathrm{L})$, and Prochlorococcus $\left(1.49 \times 10^{4} \pm 179 \mathrm{cell} / \mathrm{mL}\right)$, Synechococcus $\left(5.14 \times 10^{4} \pm 1.04 \times\right.$ $\left.10^{4} \mathrm{cell} / \mathrm{mL}\right)$, picoeukaryote $\left(1.58 \times 10^{3} \pm 118 \mathrm{cell} / \mathrm{mL}\right)$ abundances in the surface water of the NRS were determined (Supplementary Table S1). Leached micro/macronutrient concentrations added by the live or UV-treated dust additions to the mesocosms were similar, representing: $\sim 48 \mathrm{nM} \mathrm{NO}_{3}+\mathrm{NO}_{2}(+34 \%$ of the ambient levels) and $\sim 2.4 \mathrm{nM} \mathrm{PO}_{4}(+30 \%), 165 \pm 2 \mathrm{nM}$ DOC $(+0.22 \%), 3.3 \mathrm{nM} \mathrm{Fe}(+39 \%), \sim 7 \mathrm{nM}$ $\mathrm{Zn}(+77 \%)$, and $<1 \mathrm{nM} \mathrm{Cu}(+28 \%)$ (Supplementary Table S2).

Although we reported results for all time points, we only included results from $20 \mathrm{~h}$ and $44 \mathrm{~h}$ after dust additions, and not $72 \mathrm{~h}$, in our statistical analysis. These time intervals were selected because this was when the maximum differences in parameters between treatments were observed. Moreover, many of the parameters began to decrease after $44 \mathrm{~h}$ (including in the control treatments), suggesting that the changes observed were more likely due to "bottle effects" than to the changes in response to nutrient or microbial additions.

\subsection{Changes in Phytoplankton and Bacterial Abundance following Dust Additions}

Chl- $a$ was measured as a proxy for total phytoplankton biomass (Figure 2A). For all treatments Chl- $a$ concentrations increased slightly $20 \mathrm{~h}$ after amendments, and then steadily decreased throughout the experiment (Figure 2A). Overall, Chl- $a$ concentrations were significantly higher in treatments amended with live dust and UV-treated dust as compared with the control 20-44 h after amendment (Table 1, Figure 2A). However, there were no significant differences between Chl- $a$ concentrations of the live dust and UV-treated dust treatments.

Table 1. The net response triggered by airborne microbes in the northern Red Sea (NRS) seawater $24-48 \mathrm{~h}$ post addition. Values were calculated as the difference between the "live dust" and "UV-treated dust". Statistically significant differences are highlighted in bold $(p<0.05)$.

\begin{tabular}{|c|c|c|}
\hline Variable & T20 h & $\mathrm{T} 48 \mathrm{~h}$ \\
\hline Chl- $a\left(\mu \mathrm{g} \mathrm{L}^{-1}\right)$ & -0.13 & -0.06 \\
\hline Prochlorococcus (Cells $\mathrm{mL}^{-1}$ ) & -2140 & -1920 \\
\hline Synechococcus (Cells mL ${ }^{-1}$ ) & -7300 & -9100 \\
\hline Picoeukaryotes (Cells mL $\left.\mathrm{L}^{-1}\right)$ & -120 & -10 \\
\hline Heterotrophic bacteria (Cells $\mathrm{mL}^{-1}$ ) & $-82,000$ & -3000 \\
\hline$P P\left(\mu g \mathrm{CL}^{-1} \mathrm{~h}^{-1}\right)$ & -0.08 & -0.52 \\
\hline $\mathrm{BP}\left(\mu \mathrm{g} \mathrm{C} \mathrm{L} \mathrm{L}^{-1} \mathrm{~h}^{-1}\right)$ & -0.32 & 0.83 \\
\hline$\beta$-Glu $\left(\right.$ nmol L $\left.{ }^{-1} \mathrm{~h}^{-1}\right)$ & 1.49 & 1.24 \\
\hline $\mathrm{APA}\left(\mathrm{nmol} \mathrm{L} \mathrm{L}^{-1} \mathrm{~h}^{-1}\right)$ & 0.20 & 0.46 \\
\hline AMA $\left(\mathrm{nmol} \mathrm{L}^{-1} \mathrm{~h}^{-1}\right)$ & 0.48 & 0.69 \\
\hline
\end{tabular}


Prochlorococcus (Figure 2B), Synechococcus (Figure 2C) and picoeukaryotes (Figure 2D) dominate autotrophic communities in the NRS during the summer time [41]. All three autotrophs' abundances were different in the dust amendments as compared with the control treatments (Figure 2B-D). Prochlorococcus abundances decreased dramatically immediately after amendment in both dust treatments, while in the control we saw a decrease at only $20 \mathrm{~h}$ after amendment (Figure 2B). There was a slight increase in all treatments at $44 \mathrm{~h}$, followed by another decrease. Prochlorococcus abundances were significantly lower in the live dust treatments (mean $3.7 \times 10^{3} \mathrm{cells} / \mathrm{mL}$ ) and UV-treated dust (mean $5.8 \times 10^{3}$ cells $/ \mathrm{mL}$ ) than in the control treatments (mean $9.0 \times 10^{3}$ cells $/ \mathrm{mL}$ ) at $20 \mathrm{~h}$ post addition (Figure 2B, Supplementary Table S3). Prochlorococcus abundance in the dust treatments remained significantly lower than the control throughout the remainder of the experiment (Figure 2B), with no significant differences between live dust and UV-treated dust at both $20 \mathrm{~h}$ and $44 \mathrm{~h}$ after amendment. Synechococcus abundances initially decreased in all treatments and increased again at $20 \mathrm{~h}$ (Figure 2C). Synechococcus abundances in the dust treatments decreased again at $44 \mathrm{~h}$ after addition and were significantly different between the control (mean $6.62 \times 10^{4}$ cells $/ \mathrm{mL}$ ), live dust (mean $4.73 \times 10^{4}$ cells $/ \mathrm{mL}$ ), and UV-treated dust (mean $5.64 \times 10^{4}$ cells $/ \mathrm{mL}$ ), treatments (Figure 2C, Supplementary Table S3). Synechococcus abundance was significantly higher in the control than in the live dust $(28 \%)$ and UV-treated dust $(14 \%)(p$-value $<0.05)$ treatments, and live dust treatments had significantly lower Synechococcus abundance $\left(-9.0 \times 10^{3}\right.$ cells $\left./ \mathrm{mL}\right)$ than the UV-treated dust treatments (Table 1, Supplementary Table S4). Picoeukaryote abundance was significantly increased in the live dust at $20 \mathrm{~h}$ and at $44 \mathrm{~h}$ (mean $4.4 \times 10^{3}$ cells $/ \mathrm{mL}$, mean $5.2 \times 10^{3}$ cells $/ \mathrm{mL}$, respectively) and UV-treated dust (mean $4.6 \times 10^{3}$ cells $/ \mathrm{mL}, 5.2 \times 10^{3}$ cells $/ \mathrm{mL}$, respectively) treatments than in the control (mean $1.9 \times 10^{3}$ cells $/ \mathrm{mL}$, mean $1.9 \times 10^{3}$ cells $/ \mathrm{mL}$, respectively) (Figure 2D, Supplementary Table S3), after which abundances declined (Figure 2D) paralleling the dynamic of total Chl-a (Figure 2A). There was no significant difference in picoeukaryote abundance between the live dust and UV-treated dust (Supplementary Table S4).
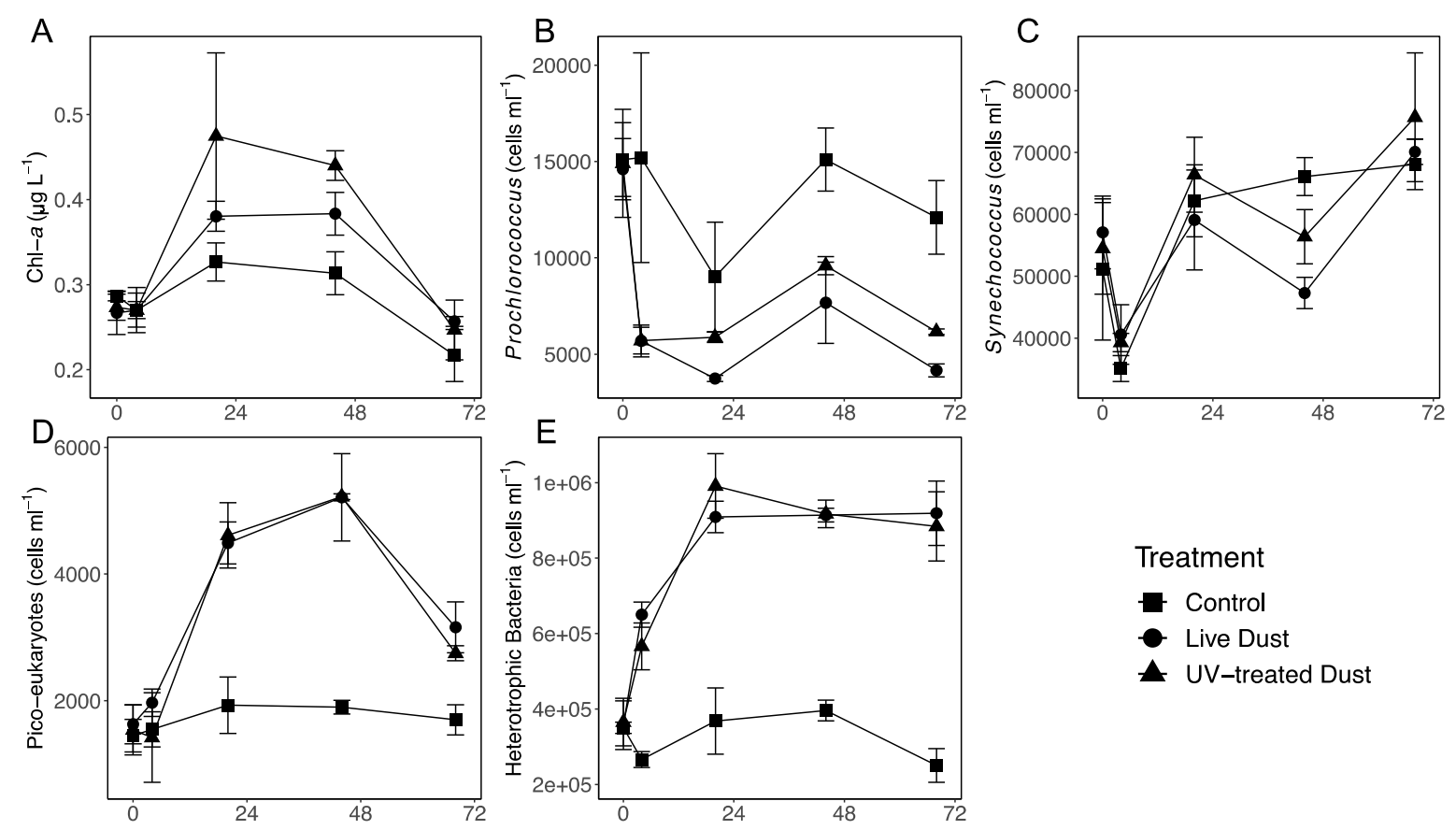

Figure 2. Temporal variability in Chl-a (A), Prochlorococcus (B), Synechococcus (C), picoeukaryotes (D), and heterotrophic bacteria (E) following $0.8 \mathrm{mg} \mathrm{L}^{-1}$ of "live dust" (circle), "UV-treated dust" (triangle) or unamended controls (square). Data shown are the average $\pm \operatorname{SD}(n=3)$. 
Heterotrophic bacterial abundance (BA) $20 \mathrm{~h}$ post-amendment in both dust treatments increased up to $\sim 150 \%$ relative to control levels, after which BA remained constant (Figure 2E). The BA in the control remained relatively stable throughout the experiment (Figure 2E). There was a significant difference ( $p$-value $<0.05$ ) in heterotrophic bacterial abundance between the control (mean $3.68 \times 10^{5} \mathrm{cell} / \mathrm{mL}$ ) and the live dust (mean $9.09 \times 10^{5} \mathrm{cell} / \mathrm{mL}$ ) and UV-treated dust (mean $9.91 \times 10^{5} \mathrm{cell} / \mathrm{mL}$ ) treatments at $20 \mathrm{~h}$, and between the control (mean $3.96 \times 10^{5} \mathrm{cell} / \mathrm{mL}$ ) and the live dust (mean $9.13 \times 10^{5} \mathrm{cell} / \mathrm{mL}$ ), and UV-treated dust (mean $9.17 \times 10^{5} \mathrm{cell} / \mathrm{mL}$ ) treatments at $44 \mathrm{~h}$ (Figure 2E, Supplementary Tables S3 and S4). There were no significant differences in BA between the live dust and UV-treated dust (Supplemental Table S4).

\subsection{Changes in Autotrophic and Heterotrophic Production following Dust Additions}

Rates of primary production (PP) in all the treatments were relatively constant throughout the experiment with small differences between dust and control treatments, aside from $44 \mathrm{~h}$ after amendment (Figure 3A). The PP in live dust (20 h mean $0.66 \mu \mathrm{g} \mathrm{C} \mathrm{L}^{-1} \mathrm{~h}^{-1}, 44 \mathrm{~h}$ mean $\left.0.74 \mu \mathrm{g} \mathrm{C} \mathrm{L}^{-1} \mathrm{~h}^{-1}\right)$, and UV-treated dust ( $20 \mathrm{~h}$ mean $0.74 \mu \mathrm{g} \mathrm{C} \mathrm{L} \mathrm{C}^{-1} \mathrm{~h}^{-1}, 44 \mathrm{~h}$ mean $1.25 \mu \mathrm{g} \mathrm{C} \mathrm{L}^{-1} \mathrm{~h}^{-1}$ ) treatments were significantly higher than the control ( $20 \mathrm{~h}$ mean $0.58 \mu \mathrm{g} \mathrm{C} \mathrm{L}-1 \mathrm{~h}^{-1}, 44 \mathrm{~h}$ mean $\left.0.60 \mu \mathrm{g} \mathrm{C} \mathrm{L}^{-1} \mathrm{~h}^{-1}\right)$ at $20 \mathrm{~h}$ and $44 \mathrm{~h}$ (Figure 3A, Supplementary Table S3). At $44 \mathrm{~h}$, PP rates were significantly lower in the live dust treatments than in UV-treated dust treatments, with a net difference of $0.52 \mu \mathrm{g} \mathrm{C} \mathrm{L}^{-1} \mathrm{~h}^{-1}$ (Table 1 , Supplementary Table S4).
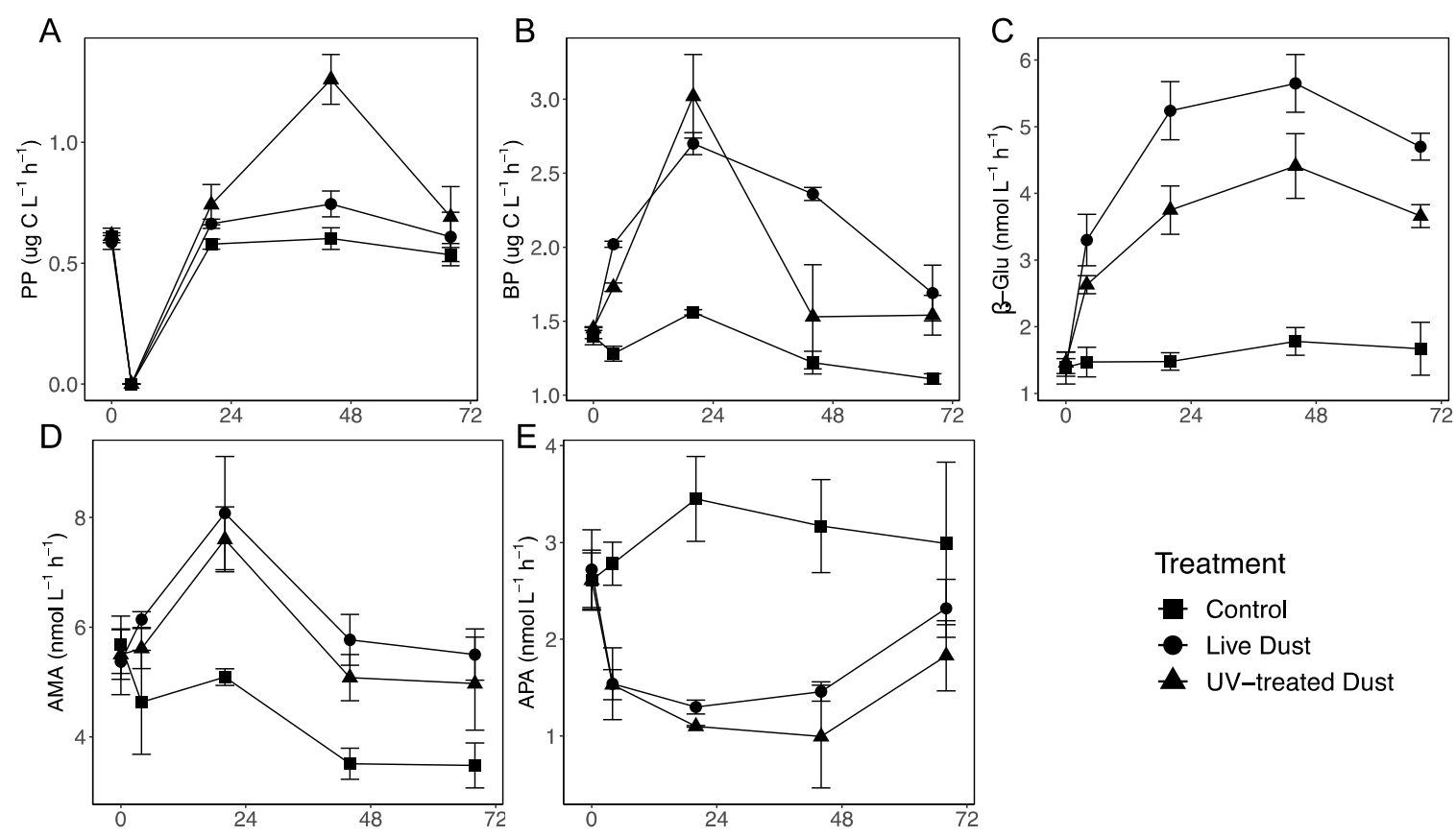

Figure 3. Temporal variability in primary production (PP) (A), bacterial production (BP) (B), beta-glucosidase $(\beta-G l u)(C)$, leu-aminopeptidase (AMA) $(D)$, and alkaline phosphatase activity (APA) (E) following $0.8 \mathrm{mg} \mathrm{L}^{-1}$ of "live dust" (circle), "UV-treated dust" (triangle) or unamended controls (square). Data shown are the average $\pm \mathrm{SD}(n=3)$.

Rates of heterotrophic bacterial production (BP) increased in the live dust (mean $2.70 \mu \mathrm{g} \mathrm{C} \mathrm{L}^{-1} \mathrm{~h}^{-1}$ ) and UV-treated dust (mean $3.02 \mu \mathrm{g} \mathrm{C} \mathrm{L} \mathrm{C}^{-1} \mathrm{~h}^{-1}$ ), treatments $20 \mathrm{~h}$ after amendment, and were significantly higher than rates of BP in the control (mean $1.56 \mu \mathrm{g} \mathrm{C} \mathrm{L}^{-1} \mathrm{~h}^{-1}$ ) (Figure 3B, Supplementary Table S3), respectively. At $44 \mathrm{~h}$ after amendment, $\mathrm{BP}$ rates decreased in the UV-treated dust treatments (mean $1.53 \mu \mathrm{g} \mathrm{C} \mathrm{L} \mathrm{L}^{-1} \mathrm{~h}^{-1}$ ) drastically while the live dust (mean $2.36 \mu \mathrm{g} \mathrm{C} \mathrm{L}^{-1} \mathrm{~h}^{-1}$ ) remained relatively stable (Figure 3B). Live dust treatments with airborne microbes had significantly higher rates of BP than both control and UV-treated dust treatments (Supplementary Table S4). The net BP rates of airborne 
microbes (difference between average BP rates in live and UV-treated treatments) was $0.83 \mu \mathrm{g} \mathrm{C} \mathrm{L}^{-1} \mathrm{~h}^{-1}$ (Table 1).

Extracellular enzymatic activity rates were used as additional measures of the activity of different groups of organisms. Beta-glucosidase ( $\beta$-Glu) (Figure 3C) and leu-aminopeptidase (AMA) (Figure 3D) activities were used to measure the extracellular enzymatic activity of heterotrophic prokaryotes, whereas alkaline phosphatase activity (APA) (Figure 3E) rates were used to measure extracellular enzymatic activity of algae.

While $\beta$-Glu activity rates of the control remained relatively constant throughout the experiment ( $20 \mathrm{~h}$ mean $1.48 \mathrm{nM} \mathrm{L}^{-1} \mathrm{~h}^{-1}, 44 \mathrm{~h}$ mean $\left.1.78 \mathrm{nM} \mathrm{L}^{-1} \mathrm{~h}^{-1}\right), \beta$-Glu activity rates of the live dust $(20 \mathrm{~h}$ mean $5.24 \mathrm{nM} \mathrm{L}^{-1} \mathrm{~h}^{-1}, 44 \mathrm{~h}$ mean $\left.5.66 \mathrm{nM} \mathrm{L}^{-1} \mathrm{~h}^{-1}\right)$ and UV-treated dust $\left(20 \mathrm{~h}\right.$ mean $3.75 \mathrm{nM} \mathrm{L}^{-1} \mathrm{~h}^{-1}$, $44 \mathrm{~h}$ mean $4.41 \mathrm{nM} \mathrm{L}^{-1} \mathrm{~h}^{-1}$ ) treatments increased significantly $20 \mathrm{~h}$ and $44 \mathrm{~h}$ after amendments (Figure 3C). The B-Gl activity rates were significantly higher in live dust treatments than UV-treated dust treatments (Supplementary Table S4), with airborne microbes contributing up to $1.24 \mathrm{nM} \mathrm{L}^{-1} \mathrm{~h}^{-1}$ (Table 1). The AMA rates in the live dust'(mean $8.08 \mathrm{nM} \mathrm{L}^{-1} \mathrm{~h}^{-1}$ ) and UV-treated dust (mean $7.59 \mathrm{nM} \mathrm{L}^{-1} \mathrm{~h}^{-1}$ ) treatments increased $20 \mathrm{~h}$ after amendment, whereas AMA rates in the control decreased (mean $5.09 \mathrm{nM} \mathrm{L}^{-1} \mathrm{~h}^{-1}$ ) (Figure 3D, Supplementary Table S4). At both timepoints, both UV-treated dust and live dust treatments had higher rates of AMA $(64 \%$ and $45 \%$, respectively at $44 \mathrm{~h}$ ) than the control ( $p$-value $<0.05$ ), but no significant differences between the live and UV-treated treatments were observed (Figure 3D, Supplementary Table S4).

The APA rates decreased for both live dust (mean $1.3 \mathrm{nM} \mathrm{L}^{-1} \mathrm{~h}^{-1}$ ) and UV-treated dust (mean $1.097 \mathrm{nM} \mathrm{L}^{-1} \mathrm{~h}^{-1}$ ) treatments while rates in the control (mean $3.45 \mathrm{nM} \mathrm{L}^{-1} \mathrm{~h}^{-1}$ ) increased $20 \mathrm{~h}$ after amendment (Figure 3E). There were no significant differences in the APA rates between the live and UV-treated dust throughout the experiment (Supplementary Table S4).

\subsection{Dust-Associated Prokaryotes and Eukaryotes}

The prokaryotic community in the dust sample collected and used in this experiment was comprised of bacteria from the Firmicutes (15\%), Gemmatimonadetes (15\%), Actinobacteria (13\%) and Bacteroidetes (12\%) phyla (Figure $4 \mathrm{~A})$. A large portion of prokaryotes (30\%) were bacteria phyla that individually made up less than $1 \%$ of the relative abundance (Figure $4 \mathrm{~A}$ ). The eukaryotic community in the aerosols was dominated by Dikarya (55\%), a subkingdom of Fungi containing the Ascomycota and Basidiomycota phyla, and Phragmoplastophyta (29\%), a subclade of Charophyta (Figure 4B). All the organisms in the Phragmoplastophyta subclade were land plants (Supplementary Table S5). Of the eukaryotes in the dust, at least 8\% were marine organisms (algae, protists) (Supplementary Table S5). 
A

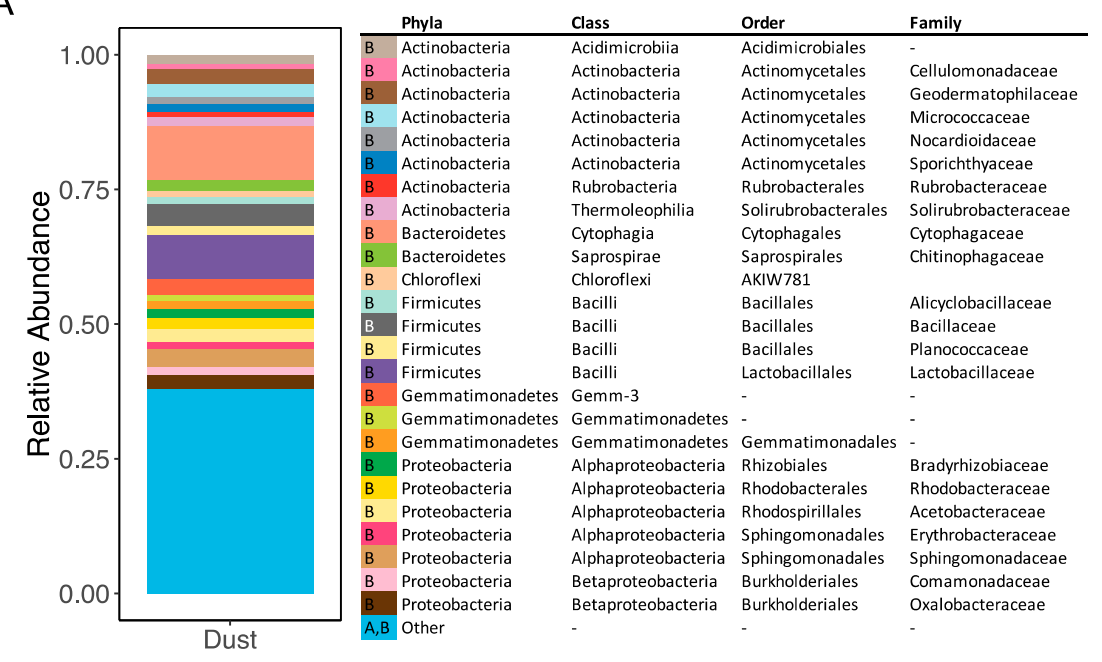

B

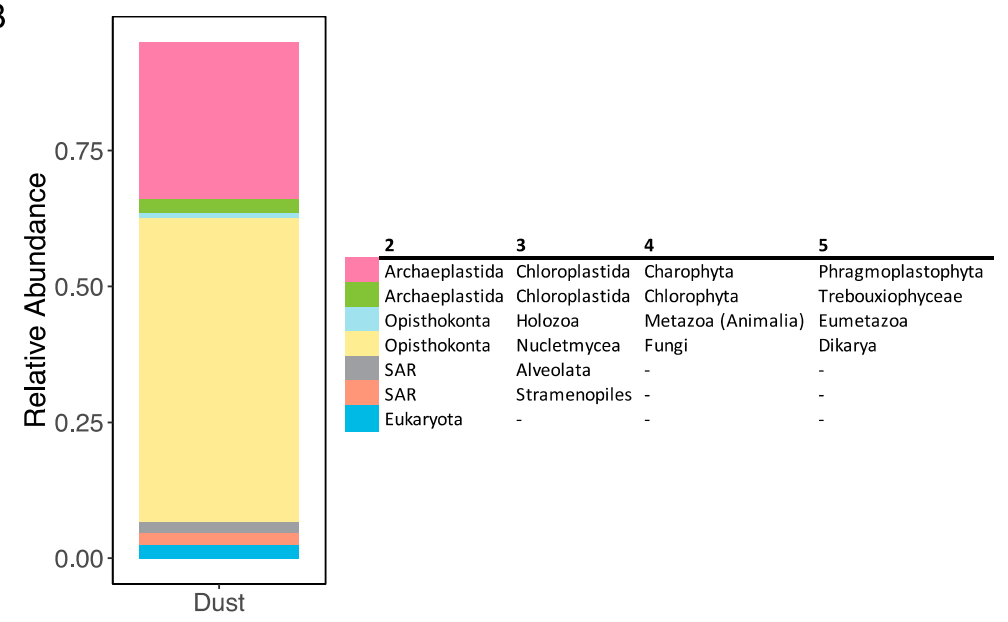

Figure 4. Relative abundance of prokaryotes (A) and eukaryotes (B) in the aerosols collected during the dust storm. The last row in both legends is the sum of all rare taxa (constituting $<5 \%$ of relative abundance). In (A), A and B in the first column of the legend corresponds to archaea and bacteria, respectively. In (B), column names $2-5$ represent taxonomic levels.

\subsection{Changes in Prokaryotic and Eukaryotic Diversity following Dust Addition}

The prokaryotic community in the NRS surface water was dominated by Proteobacteria constituting $\sim 60 \%$ of taxa before the experiment, and $\sim 70 \%$ to $75 \%$ during the experiment (Figure $5 \mathrm{~A}$ ). Alphaproteobacteria and Gammaproteobacteria were also abundant classes, making up 40-48\% and $17-25 \%$ of the community, respectively (Figure 5A). Shannon's diversity index $(\mathrm{H})$ and Faith's phylogenetic diversity (FPD) index were used to characterize the diversity of prokaryotes (Figure 6). At both timepoints $(20 \mathrm{~h}, 44 \mathrm{~h})$, the diversity (H and FPD) was significantly different between the control and the dust treatments (Figure 6, Supplementary Figure S1). At $20 \mathrm{~h}$, the prokaryotic diversity ( $\mathrm{H}$ and FPD) of the control (mean $\mathrm{H}=8.1$, mean FPD $=21.2$ ) was significantly higher than in both the live dust (mean $\mathrm{H}=7.4$, mean FPD = 13.0) and the UV-treated dust (mean $\mathrm{H}=7.6$, mean FPD = 14.4) treatments (Kruskal-Wallis test: $\mathrm{H}=3.857, \mathrm{df}=2, p<0.05$ ) (Figure 6, Supplementary Figure S1). The opposite trend was seen at $44 \mathrm{~h}$ after amendment, where the diversity (H and FPD) of both live dust (mean $\mathrm{H}=8.0$, mean FPD $=19.9$ ) and UV-treated dust (mean $\mathrm{H}=7.9$, mean FPD $=17.7$ ) treatments was higher than the that of the control (mean $\mathrm{H}=7.5$, mean FPD $=14.8$ ) (Kruskal-Wallis test: $\mathrm{H}=3.857$, $\mathrm{df}=2, p<0.05$ ) (Figure 6, Supplementary Figure S1). Similarly, beta diversity (Bray-Curtis) showed no differences between the live dust and UV-treated dust treatments at $20 \mathrm{~h}$ and $44 \mathrm{~h}$ after amendment. 


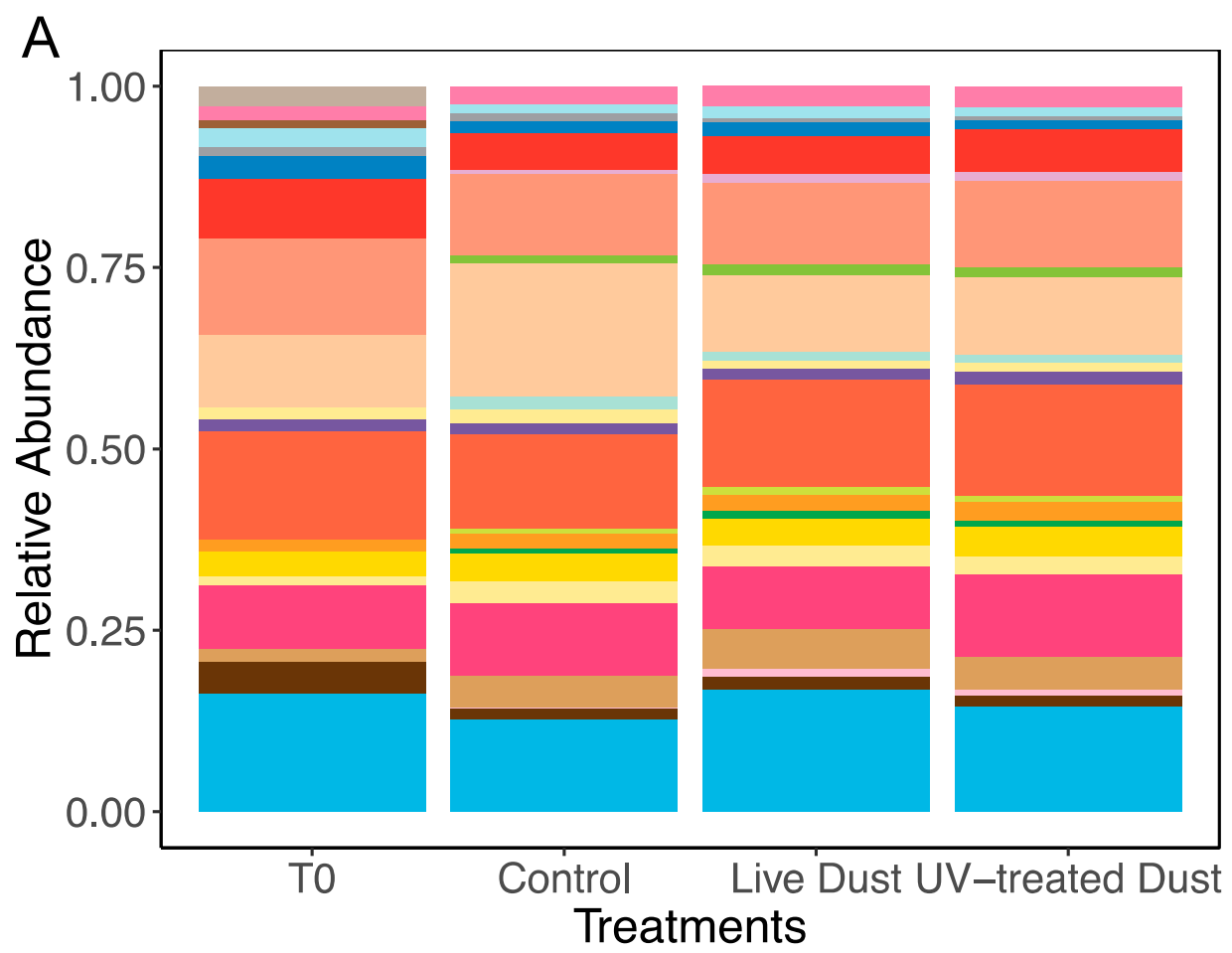

\begin{tabular}{|c|c|c|c|c|}
\hline & Phyla & Class & Order & Family \\
\hline A & Euryarchaeota & Thermoplasmata & $\mathrm{E} 2$ & Marine group II \\
\hline B & Actinobacteria & Acidimicrobiia & Acidimicrobiales & OCS155 \\
\hline B & Bacteroidetes & Cytophagia & Cytophagales & Flammeovirgaceae \\
\hline B & Bacteroidetes & Flavobacteriia & Flavobacteriales & - \\
\hline B & Bacteroidetes & Flavobacteriia & Flavobacteriales & Cryomorphaceae \\
\hline B & Bacteroidetes & Flavobacteriia & Flavobacteriales & Flavobacteriaceae \\
\hline B & Cyanobacteria & Synechococcophycideae & Synechococcales & Synechococcaceae \\
\hline B & Proteobacteria & - & - & - \\
\hline B & Proteobacteria & Alphaproteobacteria & - & - \\
\hline B & Proteobacteria & Alphaproteobacteria & Kiloniellales & - \\
\hline B & Proteobacteria & Alphaproteobacteria & Rhodobacterales & Rhodobacteraceae \\
\hline B & Proteobacteria & Alphaproteobacteria & Rhodospirillales & Rhodospirillaceae \\
\hline B & Proteobacteria & Alphaproteobacteria & Rickettsiales & - \\
\hline B & Proteobacteria & Alphaproteobacteria & Rickettsiales & AEGEAN112 \\
\hline B & Proteobacteria & Alphaproteobacteria & Rickettsiales & Pelagibacteraceae \\
\hline B & Proteobacteria & Deltaproteobacteria & Sva0853 & - \\
\hline B & Proteobacteria & Gammaproteobacteria & Alteromonadales & Alteromonadaceae \\
\hline B & Proteobacteria & Gammaproteobacteria & Alteromonadales & HTCC2188 \\
\hline B & Proteobacteria & Gammaproteobacteria & Alteromonadales & OM60 \\
\hline B & Proteobacteria & Gammaproteobacteria & Legionellales & Coxiellaceae \\
\hline B & Proteobacteria & Gammaproteobacteria & Oceanospirillales & Halomonadaceae \\
\hline B & Proteobacteria & Gammaproteobacteria & Oceanospirillales & Oceanospirillaceae \\
\hline B & Proteobacteria & Gammaproteobacteria & Oceanospirillales & Oleiphilaceae \\
\hline B & SAR406 & AB16 & Arctic96B-7 & A714017 \\
\hline B & Bacteria & - & - & - \\
\hline
\end{tabular}

Figure 5. Cont. 


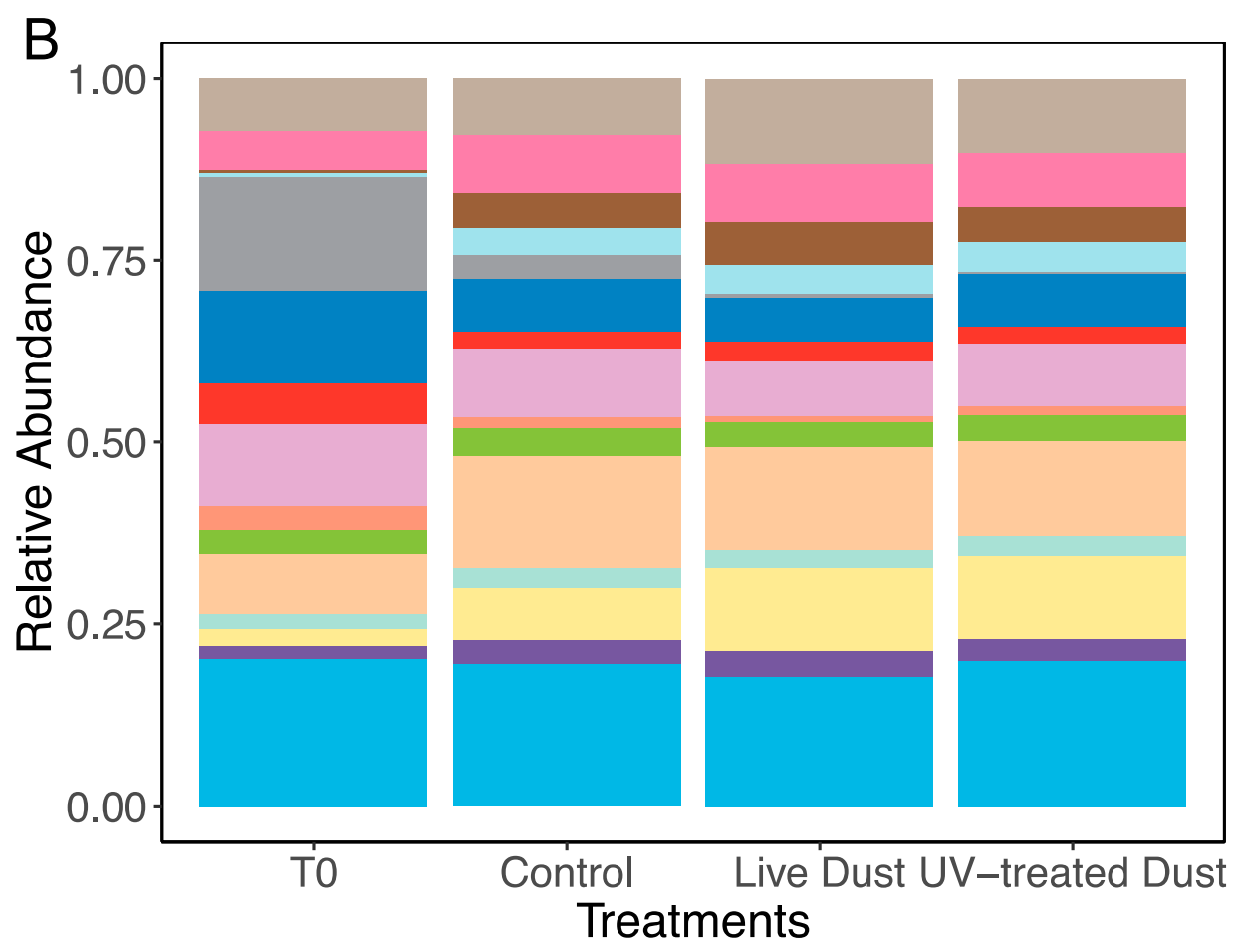

\begin{tabular}{llll}
$\mathbf{2}$ & $\mathbf{3}$ & $\mathbf{4}$ & $\mathbf{5}$ \\
\hline Archaeplastida & Chloroplastida & Chlorophyta & Mamiellophyceae \\
Haptophyta & Prymnesiophyceae & Prymnesiales & - \\
Incertae Sedis & Palpitomonas & - & - \\
Incertae Sedis & - & - & - \\
Opisthokonta & Holozoa & Metazoa (Animalia) & - \\
SAR & Alveolata & Dinoflagellata & Dinophyceae \\
SAR & Alveolata & Dinoflagellata & - \\
SAR & Alveolata & Protalveolata & Syndiniales \\
SAR & Alveolata & - & - \\
SAR & Stramenopiles & - & - \\
SAR & Stramenopiles & MAST & - \\
SAR & Stramenopiles & Ochrophyta & Chrysophyceae \\
SAR & Stramenopiles & Ochrophyta & Diatomea \\
SAR & Stramenopiles & Ochrophyta & Dictyochophyceae \\
Eukaryota & - & - & -
\end{tabular}

Figure 5. Relative abundance of prokaryotes (A) and eukaryotes (B) in the NRS surface water before amendment (T0) and $44 \mathrm{~h}$ after amendment for control, live dust, and UV-treated dust treatments. Data shown are the sum of triplicates. The last row in both legends is the sum of all rare taxa (constituting $<5 \%$ of relative abundance). In (A), A and B in the first column of the legend corresponds to archaea and bacteria, respectively. In (B), column names $2-5$ represent taxonomic levels. 
A

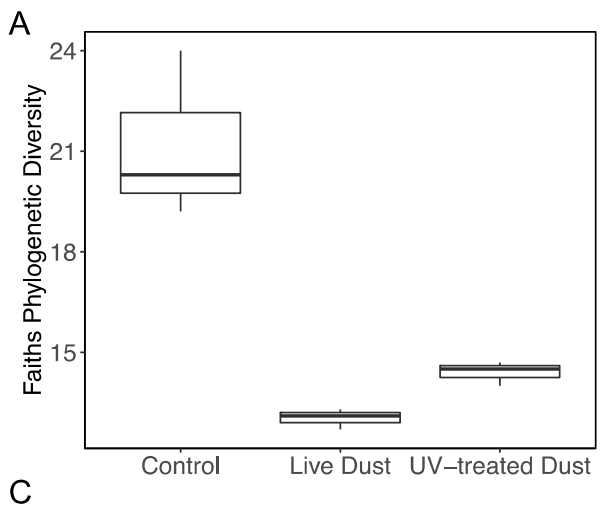

C

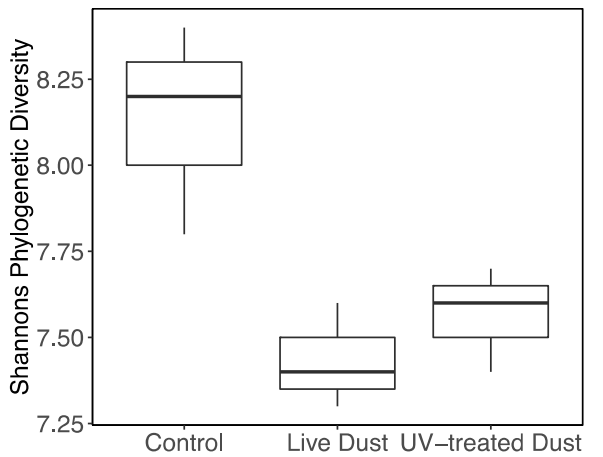

$\mathrm{E}$

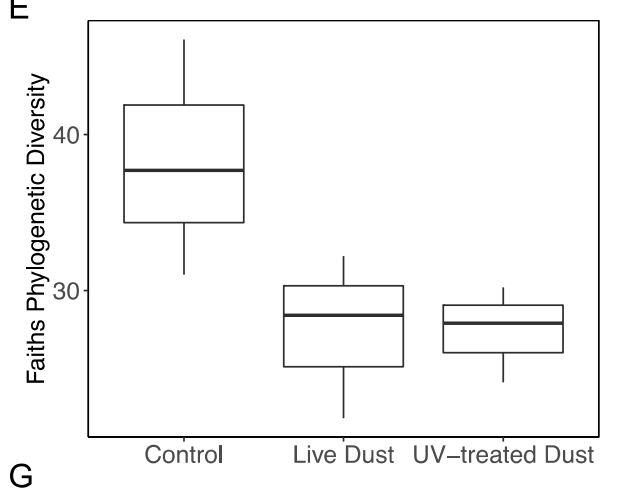

G

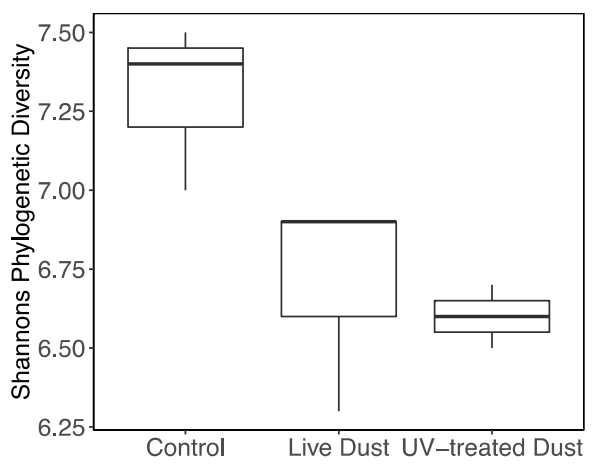

B

$\mathrm{D}$
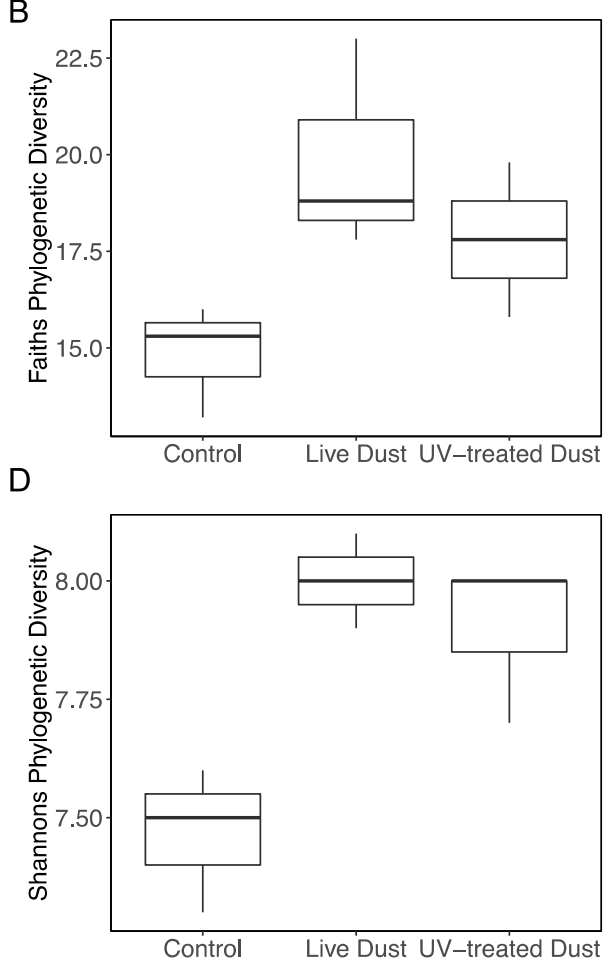

$\mathrm{F}$

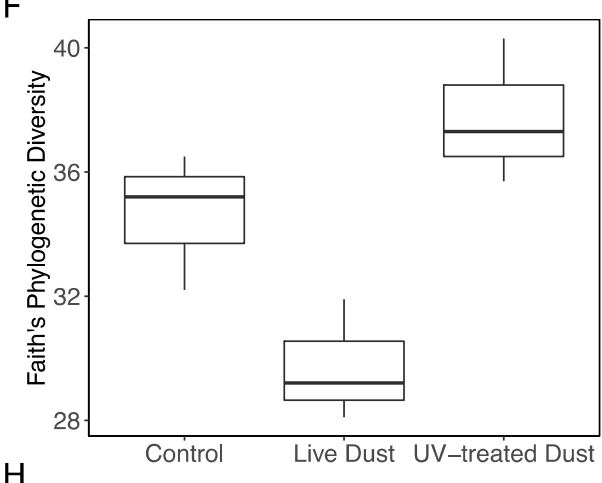

$\mathrm{H}$

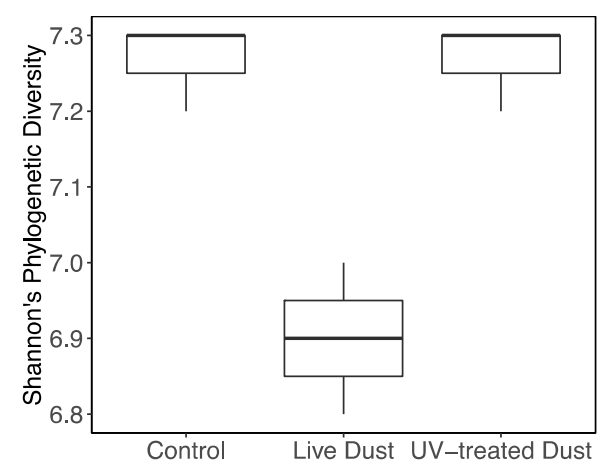

Figure 6. Diversity indices of prokaryotes, (A) Shannon's diversity indices at $20 \mathrm{~h}$ (B) Faith's phylogenetic diversity indices at $20 \mathrm{~h}$, (C) Shannon's diversity indices at $44 \mathrm{~h}$ (D) Faith's phylogenetic diversity indices at $44 \mathrm{~h}$, and diversity indices of eukaryotes, (E) Shannon's diversity indices at $20 \mathrm{~h}$ (F) Faith's phylogenetic diversity indices at $20 \mathrm{~h}$, (G) Shannon's diversity indices at $44 \mathrm{~h}$ (H) Faith's phylogenetic diversity indices at $44 \mathrm{~h}$, for control, live dust, and UV-treated dust treatments. The ends of the box are the upper and lower quartiles, so the box spans the interquartile range. The median for each treatment of three replicates is marked by a horizontal line inside the box. The whiskers are the two lines outside the box that extend to the highest and lowest observations. 
The eukaryotic community of the NRS was dominated by Alveolata (Dinoflagellata and Protalveolata) before the experiment (33\%) and by Stramenopiles (Marine Stramenopiles and Ochrophyta) (33\%) during the experiment (Figure 5B). The diversity of eukaryotes was also measured using Shannon's diversity $(\mathrm{H})$ and Faith's phylogenetic diversity (FPD) indices (Figure 6). The control (mean $\mathrm{H}=7.3$, mean FPD $=38.2$ ) had higher diversity than that in the live dust (mean $\mathrm{H}=6.7$ ) and UV-treated dust (mean $\mathrm{H}=6.6$ and mean FPD $=27.3$ ) treatments $20 \mathrm{~h}$ after amendment (Kruskal-Wallis test: $\mathrm{H}=3.857, \mathrm{df}=2, p<0.05$ ), with no differences between the live dust and UV-treated dust (Figure 6, Supplementary Figure S1). At $44 \mathrm{~h}$ after amendment, the live dust treatments (mean $\mathrm{H}=6.9$, mean FPD $=29.7$ ) had lower diversity than both the UV-treated dust (mean $\mathrm{H}=7.3$, mean FPD $=37.8$ ) and the control (mean $\mathrm{H}=7.3$, mean FPD = 34.6) treatments (Figure 6). The beta diversity (Bray-Curtis) showed no differences between the live dust and UV-treated dust treatments at $20 \mathrm{~h}$ and $44 \mathrm{~h}$ after amendment.

\section{Discussion}

\subsection{Impact of Airbone Microbes (or Dust Deposition) on Phytoplankton Biomass and Primary Production}

The NRS receives high amounts of dust deposition every year, reaching dust loads of $\sim 30 \mu \mathrm{g} \mathrm{m}^{-3}$ in normal non-storm conditions and $\sim 700 \mu \mathrm{g} \mathrm{m}^{-3}$ during dust events [16-18]. Dust particles shelter and serve as a temporary habitat for microorganisms, protecting them from direct exposure to UV radiation [42,43]. Microorganisms survive long-range transport, and it has been reported that up to $25 \%$ of airborne microorganisms remain viable upon deposition [11,44] and subsequently thrive in novel marine ecosystems and impact native microbial populations and processes [13,14]. Low-nutrient, low-chlorophyll (LNLC) marine environments are strongly impacted by dust addition during high deposition events, because atmosphere is a crucial source of limiting nutrients and trace metals [19]. However, the potential effects of airborne microorganisms delivered by atmospheric deposition in these areas has been often overlooked. Specifically, several studies in LNLC systems have shown an increase in primary production rates following aerosol addition and have solely attributed this outcome to the delivery of limiting nutrients (P, N, Fe) for photosynthesis [6,13,45-53]. Picophytoplankton, including cyanobacteria (Prochlorococcus and Synechococcus) and picoeukaryotes, account for a large portion of algal biomass and primary productivity in LNLC systems [41,54-57]. Two factors that drive picophytoplankton abundance in LNLC regions are (1) nutrient availability [58,59], and (2) population decline through viral infections and lysis [60]. Previous studies have shown that atmospheric deposition affects picophytoplankton variably, both increasing abundance due to a supply of nutrients [45-47] and decreasing abundance due to a supply of toxic metals [20]. Comparing the effect of live dust potentially carrying live microorganisms and viruses (Figure 4) and UV-treated dust where microorganisms (and other biotic entities as viruses) were inactivated, we provide evidence that airborne microorganisms also have an impact on surface ecosystem.

Both live dust and UV-treated dust amendments led to an initial ( 0 to $44 \mathrm{~h}$ ) increase of phytoplankton biomass as indicated by Chl- $a$ (Figure 2A), mostly explained by the increase in picoeukaryotes (Figure 2D). This response likely resulted from the released nutrients from the dust particles that boosted cell growth (Supplementary Table S2). In contrast, cyanobacteria declined or showed small variations as compared with the control samples (Figure 2B,C). We note however that Chl- $a$ and PP at $44 \mathrm{~h}$ were lower in the live dust samples, suggesting that living constituents present in the live dust negatively impacted phytoplankton growth and primary productivity rates (Figures $2 \mathrm{~A}$ and $3 \mathrm{~A}$ ).

This effect could have resulted from the (1) introduction of competitors for the same food resources, for example heterotrophic bacteria [61,62] and/or (2) introduction of predatory and/or pathogenic entities, for example viruses [12,63]. Indeed, the dust used in the experiment contained bacteria as well as other marine organisms (Figure 4, Supplementary Table S5), which could compete with ambient phytoplankton for resources and may have served as vectors for viruses.

Viruses are abundant in desert soils, reaching concentrations of $2.2 \times 10^{3}$ to $1.1 \times 10^{7}$ virus-like particles per gram [64]. Upon aerosolization, viruses travel long distances via dust storms. The number 
of airborne viruses has been reported to increase by an order of magnitude during dust storms as compared with normal atmospheric conditions [65]. Dust storms also pick up marine viruses, which become aerosolized through wind-induced bubble bursting on ocean surface $[12,63,66]$ while traveling over oceans. Some airborne viruses have been shown to infect phytoplankton in numbers large enough to terminate entire blooms [12]. Furthermore, there are viruses known to infect cyanobacteria that are very host-specific [67], potentially explaining why the three autotrophic populations which were measured here (picoeukaryotes, Prochlorococcus and Synechococcus) responded differently during the experiment.

\subsection{Impact of Airborne Microbes (or Dust Deposition) on Heterotrophic Prokaryotes Production}

Atmospheric dust deposition has also been shown to increase heterotrophic prokaryotes production rates in LNLC systems $[5,14,46,48,68]$. While these previous studies suggested that the input of nutrients from aerosols has increased in-situ surface water BP (i.e., that of resident heterotrophic bacteria in the marine surface layer), the differences in BP between the live dust and UV-treated dust treatments show that viable airborne microbes also rapidly contribute to increasing marine BP rates (by $50 \%$, Figure $3 \mathrm{~B}$ ). Similar results, showing contributions of airborne microbes to $\mathrm{BP}$, as well as to $\mathrm{N}_{2}$ fixation, have been previously reported for southeastern Mediterranean waters $[13,14]$. The BP rates were previously tested in microcosm bioassay experiments where aerosols collected during a dust storm were added to sterile southeastern Mediterranean water and showed that BP increased by fourfold [13], corresponding to $20-50 \%$ of the typical BP rates measured in the open and coastal southeastern Mediterranean, respectively $[5,69]$. Our study furthers their findings by showing that BP rates increase with the addition of airborne microbes in non-sterile water with resident microbial community from the Gulf of Aqaba in the NRS.

Our conclusion is also supported by the enzyme activity data (Figure 3C-E). Extracellular enzymes are synthesized by microorganisms to hydrolyze polymeric substances into bioavailable monomers [70]. Measuring rates of extracellular enzyme activity therefore provide insight into productivity of marine microbes. We show that AMA and $\beta$-Gl activities increased significantly with dust addition, while APA rates decreased significantly (Figure $3 \mathrm{~A}-\mathrm{E}$ ). Synthesis of extracellular enzymes are dependent on nutrient availability (APA dependent on P, AMA and $\beta$-Gl dependent on organic carbon) and their activity rates change with the input of nutrients via atmospheric deposition [71,72]. The $\beta$-Gl activity is attributed mostly to heterotrophic bacteria [30,73], while AMA activity is attributed to heterotrophic bacteria as well as cyanobacteria, phytoplankton, and zooplankton [30,73-75] and its activities have been shown to increase after aerosol addition in a microcosm study in the Mediterranean Sea [72]. Specifically, $\beta-G 1$ is utilized in hydrolysis of cellobiose found in polymers, such as cellulose and mucopolysaccharides, and can be related to Chl-a [76,77], whereas AMA is utilized in the decay of particulate matter composed of biotic and abiotic material [74,75]. APA, synthesized by phytoplankton [73], has also been shown to vary in response to dust additions to the Mediterranean [71,72] and northern Red Sea [78] seawater during incubation experiments. Changes in enzymatic activity were observed in both the UV-treated dust and live dust treatments as compared with the control, showing that chemical components of atmospheric deposition are enhanced in-situ microbial activities, as previously suggested. However, we also measured differences in $\beta$-Gl activity rates between the UV-treated dust and live dust treatments, indicating that viable airborne microorganisms specifically contribute to increasing $\beta$-Gl activity rates (20-25\%, Figure 3C). A significant difference between UV-treated dust and live dust treatments was not observed in the AMA activity rates (Figure 3D), which is also synthesized by heterotrophic bacteria. These results suggest that deposited airborne microbes preferentially synthesized $\beta$-Gl for hydrolysis of carbohydrates, and since the chemical constituents were the same in both treatments, the preferential use of this enzyme in the live dust treatment likely corresponds to synthesis by the microbial assemblage of the dust (Figure 4A).

Interestingly, although we saw differences in the BP between treatments, the heterotrophic bacteria abundance significantly increased with the addition of dust in both treatments relative to the control 
but was not different between the live dust and UV-treated dust treatments (Figure 2B). This difference in cell specific activity (bacterial production per bacterial abundance) was previously observed in a mesocosm study in the southeastern MS [13]. We attribute this increase solely to the chemical constituents of aerosols, which provide nutrients and organic $C$ to increase heterotrophic bacteria abundance, in both treatments regardless of their origin $[5,14,46,48,68]$. Alternatively, there may be a higher removal of heterotrophic bacteria in the live dust treatments by grazing or viral lysis, preventing an increase in abundance.

\subsection{Microbial Population in the Dust and their Impact on Biodiversity}

Most of the bacteria found in the dust $(>1 \%)$ were not found in the seawater from the mesocosm experiments $(>1 \%)$ at the family level, aside from organisms belonging to the family Rhodobacteraceae (Figures 4A and 5A). However, there was a large number of eukaryotes (Alveolates and Stramenopiles) present in the dust, as well as in all the seawater samples (Figures $4 \mathrm{~B}$ and $5 \mathrm{~B}$ ). These organisms made up $8 \%$ of the dust (Figure $4 \mathrm{~B}$, Supplementary Table S5), and up to $52 \%$ of the seawater samples. These marine organisms likely become aerosolized from ocean surfaces through bubble bursting and sea spray $[12,63,66]$.

We found similar taxonomic relative abundances in all treatments at $44 \mathrm{~h}$ after amendment (Figure 5), however this visual representation is not sensitive enough to detect differences in diversity. Therefore, to quantitatively assess community differences we calculated diversity of both prokaryotes and eukaryotes of treatments (live dust, UV-treated dust, and control) (Figure 6, Supplementary Figure S1) using alpha diversity metrics. Alpha diversity metrics are used quantitatively (Shannon's diversity index), qualitatively (Faith's phylogenetic diversity), and phylogenetically (Faith's phylogenetic diversity) to show how many unique taxa are present in a sample. Our experiment showed that eukaryote diversity (both measures) was different between live dust and UV-treated dust treatments at $44 \mathrm{~h}$, with significantly lower diversity when airborne microbes were present (Figure 6). The lower diversity in the live dust treatments indicate that the number of unique eukaryotes in the NRS surface water decreased with the addition of airborne microbes. The difference in diversity may be a result of competitive relationships between airborne microbes and eukaryotes in the NRS surface water. Alternatively, airborne viruses or fungi in our sample may have specifically infected certain marine eukaryote groups. However, the diversity of prokaryotes did not change between treatments, indicating that there was no antagonistic relationship between the bioaerosols and bacterial communities of the NRS. These processes need to be further studied.

\section{Conclusions}

Our results show that microbial diversity is altered by bioaerosols and that while the rates of primary productivity decline, the rates of bacterial production increase in response to the deposition of bioaerosols. Since our experiment lasted $72 \mathrm{~h}$, with most changes occurring in the first $48 \mathrm{~h}$, the observed effects of bioaerosols might be transient. Although our study was conducted in mesocosms and lasted only $\sim 72 \mathrm{~h}$, surface water with local microbial assemblages was used and the amount of aerosol added was representative of conditions during dust storm events. The results are consistent with previous reports indicating that atmospheric deposition is a crucial source of nutrients and trace metals in LNLC systems $[2,3,79,80]$. However, we also clearly show unique effects of airborne microorganisms impacting biogeochemical processes indicating that the impact of bioaerosols is also relevant, particularly in LNLC regions where dust storm events occur. Importantly, since dust deposition is predicted to increase with climate change, the impact of airborne microorganisms found in our study may also increase. Additional studies that improve our understanding of how these geographically vast areas of ocean will be impacted by bioaerosols will be of great value.

Supplementary Materials: The following are available online at http://www.mdpi.com/2073-4433/10/7/358/s1: Figure S1. Alpha diversity (Faith's phylogenetic or Shannon's diversity indices) for control, "live dust", "UV-treated dust" treatments; (A) Shannon's diversity index (DI) for prokaryotes at 20 h; (B) Faith's phylogenetic diversity 
(PD) for prokaryotes at 20 h; (C) Shannon's DI for prokaryotes at 44 h; (D) Faith's PD for prokaryotes at 44 h; (E) Shannon's DI for eukaryotes at 20 h; (F) Faith's PD for eukaryotes at 20 h.; Table S1. Chemical and biological properties of the NRS water used in the experiment (before amendments); Table S2. Nutrients and trace metals concentrations added from the aerosols to each mesocosm; Table S3. ANOVA test results between control, "UV-treated" and "live-dust' treatments at $20 \mathrm{~h}$ or $44 \mathrm{~h}$; Table S4. Tukey post-hoc test results between "UV-treated" and control, "live-dust" and control and "live-dust" and "UV-treated' treatments at $20 \mathrm{~h}$ or $44 \mathrm{~h}$; Table S5. Eukaryotes, relative abundances (abundance), and general information on taxa (details).

Author Contributions: Project administration and design A.P.; Writing—original draft, E.M.; Writing-review and editing, E.M., A.P., E.R., M.J.F., S.R., O.R., Y.G., C.S., and B.H.

Acknowledgments: This study was supported by the Israel Science Foundation (grant 1211/17) to B. H and E. R and by the NSF-OCE (grant 0850467) and the NSF-OISE (grant 1358134) to A. P. E.M was supported by the NSF GRFP. Y. G. was supported by the Banca del Monte di Lombardia Foundation. We would like to thank Wan-Chen $\mathrm{Tu}$ for her contribution on the trace metal analysis. The authors thank the personnel in the InterUniversity Institute for Marine Sciences in Eilat (IUI).

Conflicts of Interest: The authors declare no conflict of interest.

\section{References}

1. Herut, B.; Collier, R.; Krom, M.D. The role of dust in supplying nitrogen and phosphorus to the southeast Mediterranean. Limnol. Oceanogr. 2002, 47, 870-878. [CrossRef]

2. Jickells, T.D.; An, Z.S.; Anderson, K.K.; Baker, A.R.; Bergametti, G.; Brooks, N.; Cao, J.J.; Boyd, P.W.; Duce, R.A.; Hunter, K.A.; et al. Global iron connections between desert dust, ocean biogeochemistry, and climate. Science 2005, 308, 67-71. [CrossRef]

3. Duce, R.A.; LaRoche, J.; Altieri, K.; Arrigo, K.R.; Baker, A.R.; Capone, D.G.; Cornell, S.; Dentener, F.; Galloway, J.; Ganeshram, R.S.; et al. Impacts of atmospheric anthropogenic nitrogen on the open ocean. Science 2008, 320, 893-897. [CrossRef]

4. $\quad$ Duce, R.A.; Liss, P.S.; Merrill, J.T.; Elliot, A.L.; Buat-Menard, P.; Hicks, B.B.; Miller, J.M.; Prospero, J.M.; Arimoto, R.; Church, T.M.; et al. The atmospheric input of trace species to the world ocean. Glob. Biogeochem. Cycles 1991, 5, 193-259. [CrossRef]

5. Pulido-Villena, E.; Wagener, T.; Guieu, C. Bacterial response to dust pulses in the western Mediterranean: Implications for carbon cycling in the oligotrophic ocean. Glob. Biogeochem. Cycles 2008, 22, GB1020. [CrossRef]

6. Herut, B.; Rahav, E.; Tsagaraki, T.M.; Giannakourou, A.; Tsiola, A.; Psarra, S.; Lagaria, A.; Papageorgiou, N.; Mihalopoulos, N.; Theodosi, C.N.; et al. The potential impact of Saharan dust and polluted aerosols on microbial populations in the east Mediterranean Sea, an overview of a mesocosm experimental approach. Front. Mar. Sci. 2016, 3, 226. [CrossRef]

7. Rahav, E.; Paytan, A.; Mescioglu, E.; Galletti, Y.; Rosenfeld, S.; Raveh, O.; Santinelli, C.; Ho, T.; Herut, B. Airborne microbes contribute to $\mathrm{N}_{2}$ fixation in surface water of the Northern Red Sea. Geophys. Res. Lett. 2018, 2-10. [CrossRef]

8. Kellogg, C.A.; Griffin, D.W. Aerobiology and the global transport of desert dust. Trends Ecol. Evol. 2006, 21, 638-644. [CrossRef]

9. Griffin, D.W.; Kubilay, N.; Kocak, M.; Gray, M.A.; Borden, T.C.; Shinn, E.A. Airborne desert dust and aeromicrobiology over the Turkish Mediterranean coastline. Atmos. Environ. 2007, 41. [CrossRef]

10. Mayol, E.; Arrieta, J.M.; Jiménez, M.A.; Martínez-Asensio, A.; Garcias-Bonet, N.; Dachs, J.; González-Gaya, B.; Royer, S.J.; Benítez-Barrios, V.M.; Fraile-Nuez, E.; et al. Long-range transport of airborne microbes over the global tropical and subtropical ocean. Nat. Commun. 2017, 8, 1-8. [CrossRef]

11. Womack, A.M.; Bohannan, B.J.M.; Green, J.L. Biodiversity and biogeography of the atmosphere. Philos. Trans. R. Soc. Lond. B Biol. Sci. 2010, 365, 3645-3653. [CrossRef]

12. Sharoni, S.; Trainic, M.; Schatz, D.; Lehahn, Y.; Flores, M.J.; Bidle, K.D.; Ben-Dor, S.; Rudich, Y.; Koren, I.; Vardi, A. Infection of phytoplankton by aerosolized marine viruses. Proc. Natl. Acad. Sci. USA 2015, 112, 6643-6647. [CrossRef]

13. Rahav, E.; Ovadia, G.; Paytan, A.; Herut, B. Contribution of airborne microbes to bacterial production and $\mathrm{N}_{2}$ fixation in seawater upon aerosol deposition. Geophys. Res. Lett. 2016, 43, 719-727. [CrossRef] 
14. Rahav, E.; Paytan, A.; Chien, C.-T.; Ovadia, G.; Katz, T.; Herut, B. The impact of atmospheric dry deposition associated microbes on the southeastern Mediterranean Sea surface water following an intense dust storm. Front. Mar. Sci. 2016, 3. [CrossRef]

15. Antoine, D.; André, J.M.; Morel, A. Oceanic primary production: 2. Estimation at global scale from satellite. coastal zone color scanner) chlorophyll. Glob. Biogeochem. Cycles 1996, 10, 57-69. [CrossRef]

16. Lawrence, C.R.; Neff, J.C. The contemporary physical and chemical flux of aeolian dust: A synthesis of direct measurements of dust deposition. Chem. Geol. 2009, 267, 46-63. [CrossRef]

17. Torfstein, A.; Teutsch, N.; Tirosh, O.; Shaked, Y.; Rivlin, T.; Zipori, A.; Stein, M.; Lazar, B.; Erel, Y. Chemical characterization of atmospheric dust from a weekly time series in the north Red Sea between 2006 and 2010. Geochim. Cosmochim. Acta 2017, 211, 373-393. [CrossRef]

18. Chen, Y.; Mills, S.; Street, J.; Golan, D.; Post, A.; Jacobson, M.; Paytan, A. Estimates of atmospheric dry deposition and associated input of nutrients to Gulf of Aqaba. J. Geophys. Res. 2007, 112, 04309. [CrossRef]

19. Guieu, C.; Aumont, O.; Paytan, A.; Bopp, L.; Law, C.S.; Mahowald, N.; Achterberg, E.P.; Marañón, E.; Salihoglu, B.; Crise, A.; et al. Global biogeochemical cycles deposition to Low Nutrient Low Chlorophyll regions. Glob. Biogeochem. Cycles 2014, 28, 1179-1198. [CrossRef]

20. Paytan, A.; Mackey, K.R.M.; Chen, Y.; Lima, I.D.; Doney, S.C.; Mahowald, N.; Labiosa, R.; Post, A.F. Toxicity of atmospheric aerosols on marine phytoplankton. Proc. Natl. Acad. Sci. USA 2009, 106, 4601-4605. [CrossRef]

21. Katra, I.; Arotsker, L.; Krasnov, H.; Zaritsky, A.; Kushmaro, A.; Ben-Dov, E. Richness and diversity in dust stormborne biomes at the southeast Mediterranean. Sci. Rep. 2014, 4, 5265. [CrossRef]

22. Gat, D.; Mazar, Y.; Cytryn, E.; Rudich, Y. Origin-dependent variations in the atmospheric microbiome community in Eastern Mediterranean dust storms. Environ. Sci. Technol. 2017, 51, 6709-6718. [CrossRef]

23. Foster, R.A.; Paytan, A.; Zehr, J.P. Seasonality of $\mathrm{N}_{2}$ fixation and nifH gene diversity in the Gulf of Aqaba. Red Sea. Limnol. Oceanogr. 2009, 54, 219-233. [CrossRef]

24. Chen, Y.; Paytan, A.; Chase, Z.; Measures, C.; Beck, A.J.; Sañudo-Wilhelmy, S.A.; Post, A.F. Sources and fluxes of atmospheric trace elements to the Gulf of Aqaba, Red Sea. J. Geophys. Res. 2008, 113, 1-13. [CrossRef]

25. Jish Prakash, P.; Stenchikov, G.; Kalenderski, S.; Osipov, S.; Bangalath, H. The impact of dust storms on the Arabian Peninsula and the Red Sea. Atmos. Chem. Phys. 2015, 15, 199-222. [CrossRef]

26. Simon, M.; Alldredge, A.; Azam, F. Bacterial carbon dynamics on marine snow. Mar. Ecol. Prog. 1990, 65, 205-211. [CrossRef]

27. Simon, M.; Alldredge, A.; Azam, F. Protein-content and protein-synthesis rates of planktonic marine-bacteria. Mar. Ecol. Prog. 1989, 51, 201-213. [CrossRef]

28. Steemann-Nielsen, E. On the determination of the activity for measuring primary production. J. Cons. Int. Explor. Mer. 1952, 18, 117-140.

29. Welschmeyer, N.A. Fluorometric analysis of chlorophyll $\mathrm{a}$ in the presence of chlorophyll $\mathrm{b}$ and pheopigments. Limnol. Oceanogr. 1994, 39, 1985-1992. [CrossRef]

30. Hoppe, H.G. Significance of exoenzymatic activities in the ecology of brackish water: Measurements by means of methyl umbelliferyl substrates. Mar. Ecol. Prog. Ser. 1983, 11, 299-308. [CrossRef]

31. Thingstad, T.F.; Mantoura, R. Titrating excess nitrogen content of phosphorous-deficient eastern Mediterranean surface water using alkaline phosphatase activity as a bio-indicator. Limnol. Oceanogr. Methods 2005, 3, 94-100. [CrossRef]

32. Massana, R.; Murray, A.E.; Preston, C.M.; Delong, E. Vertical distribution and phylogenetic characterization of marine planktonic Archaea in the Santa Barbara Channel. Appl. Environ. Microbiol. 1997, 63, 50-56.

33. Bolyen, E.; Rideout, J.R.; Dillon, M.R.; Bokulich, N.A.; Abnet, C.; Al-Ghalith, G.A.; Alexander, H.; Alm, E.J.; Arumugam, M.; Asnicar, F. QIIME 2: Reproducible, interactive, scalable, and extensible microbiome data science. Peer J. Prepr. 2018. [CrossRef]

34. Callahan, B.J.; McMurdie, P.J.; Rosen, M.J.; Han, A.W.; Johnson, A.J.; Holmes, S.P. DADA2: High-resolution sample inference from Illumina amplicon data. Nat. Methods 2016, 13, 581-583. [CrossRef]

35. Pedregosa, F.; Varoquaux, G.; Gramfort, A.; Michel, V.; Thirion, B.; Grisel, O.; Blondel, M.; Prettenhofer, P.; Weiss, R.; Dubourg, V.; et al. Scikit-learn: Machine Learning in Python. J. Mach. Learn. Res. 2011, 12, $2825-2830$.

36. DeSantis, T.Z.; Hugenholtz, P.; Larsen, N.; Rojas, M.; Brodie, E.L.; Keller, K.; Huber, T.; Dalevi, D.; Hu, P.; Andersen, G.L. Greengenes, a chimera-checked $16 \mathrm{~S}$ rRNA gene database and workbench compatible with ARB. Appl. Environ. Microbiol. 2006, 72, 5069-5072. [CrossRef] 
37. Quast, C.; Pruesse, E.; Yilmaz, P.; Gerken, J.; Schweer, T.; Yarza, P.; Peplies, J.; Glöckner, F.O. The SILVA ribosomal RNA gene database project: Improved data processing and web-based tools. Nucleic Acids Res. 2013, 41, D590-D596. [CrossRef]

38. Bokulich, N.A.; Kaehler, B.D.; Rideout, J.R.; Dillon, M.; Bolyen, E.; Knight, R.; Huttley, G.A.; Caporaso, G.J. Optimizing taxonomic classification of marker-gene amplicon sequences with QIIME 2's q2-feature-classifier plugin. Microbiome 2018, 6, 90. [CrossRef]

39. Chase, Z.; Paytan, A.; Johnson, K.S.; Street, J.; Chen, Y. Input and cycling of iron in the Gulf of Aqaba, Red Sea. Glob. Biogeochem. Cycles 2016, 20, GB3017. [CrossRef]

40. Chase, Z.; Paytan, A.; Beck, A.; Biller, D.; Bruland, K.; Measures, C.; Sañudo-Wilhelmy, S. Evaluating the impact of atmospheric deposition on dissolved trace-metals in the Gulf of Aqaba, Red Sea. Mar. Chem. 2011, 126, 256-268. [CrossRef]

41. Lindell, D.; Post, A.F. Ultraphytoplankton succession is triggered by deep winter mixing in the Gulf of Aqaba (Eilat), Red Sea. Limnol. Oceanogr. 1995, 40, 1130-1141. [CrossRef]

42. Lighthart, B.; Shaffer, B.T. Survey of culturable airborne bacteria at four diverse locations in Oregon: Urban, rural, forest, and coastal. Microb. Ecol. 1997, 34, 167-177.

43. Pearce, D.A.; Bridge, P.D.; Hughes, K.A.; Sattler, B.; Psenner, R.; Russell, N.J. Microorganisms in the atmosphere over Antarctica. FEMS Microbiol. Ecol. 2009, 69, 143-157. [CrossRef]

44. Polymenakou, P.N. Atmosphere: A source of pathogenic or beneficial microbes? Atmosphere 2012, 3, 87-102. [CrossRef]

45. Mills, M.M.; Ridame, C.; Davey, M.; La Roche, J.; Geider, R.J. Iron and phosphorus co-limit nitrogen fixation in the eastern tropical North Atlantic. Nature 2004, 429, 292-294. [CrossRef]

46. Herut, B.; Zohary, T.; Krom, M.D.; Mantoura, R.F.C.; Pitta, P.; Psarra, S.; Rassoulzadegan, F.; Tanaka, T.; Frede Thingstad, T. Response of East Mediterranean surface water to Saharan dust: On-board microcosm experiment and field observations, Deep. Res. Part II Top. Stud. Oceanogr. 2005, 52, 3024-3040. [CrossRef]

47. Bonnet, S.; Guieu, C.; Chiaverini, J.; Ras, J.; Stock, A. Effect of atmospheric nutrients on the autotrophic communities in a low nutrient, low chlorophyll system. Limnol. Oceanogr. 2005, 50, 1810-1819. [CrossRef]

48. Marañén, E.; Fernández, A.; Mouriño-Carballido, B.; MartÍnez-GarcÍa, S.; Teira, E.; Cermeño, P.; Chouciño, P.; Huete-Ortega, M.; Fernández, E.; Calvo-Díaz, A.; et al. Degree of oligotrophy controls the response of microbial plankton to Saharan dust. Limnol. Oceanogr. 2010, 55, 2339-2352. [CrossRef]

49. Ternon, E.; Guieu, C.; Ridame, C.; L'Helguen, S.; Catala, P. Longitudinal variability of the biogeochemical role of Mediterranean aerosols in the Mediterranean Sea. Biogeosciences 2011, 8, 1067-1080. [CrossRef]

50. Ridame, C.; Guieu, C.; L'Helguen, S. Strong stimulation of $\mathrm{N}_{2}$ fixation to contrasted Saharan dust events in a Low Nutrient-Low Chlorophyll environment: Results from dust addition in large mesocosms. Biogeosciences 2013, 10, 7333-7346. [CrossRef]

51. Blain, S.; Guieu, C.; Claustre, H.; Leblanc, K.; Moutin, T.; Quéguiner, B.; Sarthou, G. Availability of iron for phytoplankton in the north-east Atlantic Ocean. Limnol. Oceanogr. 2004, 49, 2095-2104. [CrossRef]

52. Mackey, K.R.M.; Roberts, K.; Lomas, M.W.; Saito, M.A.; Post, A.F.; Paytan, A. Enhanced Solubility and Ecological Impact of Atmospheric Phosphorus Deposition upon Extended Seawater Exposure. Environ. Sci. Technol. 2012, 46, 10438-10446. [CrossRef]

53. Chien, C.-T.; Mackey, K.R.M.; Dutkiewicz, S.; Mahowald, N.M.; Prospero, J.M.; Paytan, A. Effects of African dust deposition on phytoplankton in the western tropical Atlantic Ocean off Barbados. Glob. Biogeochem. Cycles 2016, 30, 716-734. [CrossRef]

54. Partensky, F.; Blanchot, J.; Vaulot, D. Differential distribution and ecology of Prochlorococcus and Synechococcus in oceanic waters: A review. Bull. Inst. Oceanogr. Monaco Numero Spec. 1999, 19, 431-449.

55. Jardillier, L.; Zubkov, M.V.; Pearman, J.; Scanlan, D.J. Significant $\mathrm{CO}_{2}$ fixation by small prymnesiophytes in the subtropical and tropical northeast Atlantic Ocean. ISME J. 2010, 4, 1180-1192. [CrossRef]

56. Flombaum, P.; Gallegos, J.L.; Gordillo, R.A.; Rincón, J.; Zabala, L.L.; Jiao, N.; Karl, D.M.; Li, W.K.W.; Lomas, M.W.; Veneziano, D.; et al. Present and future global distributions of the marine cyanobacteria Prochlorococcus and Synechococcus. Proc. Natl. Acad. Sci. USA 2013, 1-6. [CrossRef]

57. Pearman, J.; Ellis, J.; Irigoien, X.; Sarma, Y.V.B.; Jones, B.H.; Carvalho, S. Microbial planktonic communities in the Red Sea: High levels of spatial and temporal variability shaped by nutrient availability and turbulence. Sci. Rep. 2017, 7. [CrossRef] 
58. DuRand, M.D.; Olson, R.J.; Chisholm, S.W. Phytoplankton population dynamics at the Bermuda Atlantic Time-series station in the Sargasso Sea. Deep Sea Res. 2001, 48, 8-9. [CrossRef]

59. Grossowicz, M.; Roth-Rosenberg, D.; Aharonovich, D.; Silverman, J.; Follows, M.J.; Sher, D. Prochlorococcus in the lab and in silico: The importance of representing exudation. Limnol. Oceanogr. 2017, 62, 818-835. [CrossRef]

60. Chénard, C.; Suttle, C.A. Phylogenetic diversity of sequences of cyanophage photosynthetic gene psbA in marine and freshwaters. Appl. Environ. Microbiol. 2008, 74, 5317-5324. [CrossRef]

61. Cotner, J.; Biddanda, B. Small Players, Large Role: Microbial Influence on Biogeochemical Processes in Pelagic Aquatic Ecosystems. Ecosystems 2002, 5, 105. [CrossRef]

62. Joint, I.; Henriksen, P.; Fonnes, G.A.; Bourne, D.; Thingstad, T.F.; Riemann, B. Competition for inorganic nutrients between phytoplankton and bacterioplankton in nutrient manipulated mesocosms. Aquat. Microb. Ecol. 2002, 29, 145-159. [CrossRef]

63. Reche, I.; D'Orta, G.; Mladenov, N.; Winget, D.M.; Suttle, C.A. Deposition rates of viruses and bacteria above the atmospheric boundary layer. ISME J. 2018, 12, 1154-1162. [CrossRef]

64. Gonzalez-Martin, C.; Teigell-Perez, N.; Lyles, M.; Valladares, B.; Griffin, D.W. Epifluorescent direct counts of bacteria and viruses from topsoil of various desert dust storm regions. Res. Microbiol. 2013, 164, 17-21. [CrossRef]

65. Griffin, D.W.; Garrison, V.H.; Herman, J.R.; Shinn, E.A. African desert dust in the Caribbean atmosphere: Microbiology and public health. Aerobiologia 2001, 17, 203-213. [CrossRef]

66. Lewis, G.M.; Austin, P.H.; Szczodrak, M. Spatial statistics of marine boundary layer clouds. J. Geophys. Res. 2004, 109, D04104. [CrossRef]

67. Sullivan, M.B.; Coleman, M.L.; Weigele, P.; Rohwer, F.; Chisholm, S.W. Three Prochlorococcus cyanophage genomes: Signature features and ecological interpretations. PLoS Biol. 2005, 3, 790-806. [CrossRef]

68. Reche, I.; Ortega-Retuerta, E.; Romera, O.; Pulido-Villena, E.; Morales-Baquero, R.; Casamayor, E.O. Effect of Saharan dust inputs on bacterial activity and community composition in Mediterranean lakes and reservoirs. Limnol. Oceanogr. 2009, 54, 869-879. [CrossRef]

69. Raveh, O.; David, N.; Rilov, G.; Rahav, E. The temporal dynamics of coastal phytoplankton and bacterioplankton in the Eastern Mediterranean Sea. PLoS ONE 2015, 10, 1-23. [CrossRef]

70. Chróst, R.J. Microbial Ectoenzymes in Aquatic Environments. In Aquatic Microbial Ecology; Overbeck, J., Chróst, R.J., Eds.; Brock/Springer Series in Contemporary Bioscience; Springer: New York, NY, USA, 1990.

71. Krom, M.D.; Shi, Z.; Stockdale, A.; Berman-Frank, I.; Giannakourou, A.; Herut, B.; Lagaria, A.; Papageorgiou, N.; Pitta, P.; Psarra, S.; et al. Response of the Eastern Mediterranean microbial ecosystem to dust and dust a affected by acid processing in the atmosphere. Front. Mar. Sci. 2016, 3. [CrossRef]

72. Marín, I.; Nunes, S.; Sánchez-Pérez, E.D.; Txurruka, E.; Antequera, C.; Sala, M.M.; Marrasé, C.; Peters, F. Coastal Bacterioplankton Metabolism Is Stimulated Stronger by Anthropogenic Aerosols than Saharan Dust. Front. Microbiol. 2017, 8, 2215. [CrossRef]

73. Münster, U.; Nurminen, J.; Einiö, P.; Overbeck, J. Extracellular enzymes in a small polyhumic lake: Origin, distribution and activities. Hydrobiologia 1992, 243, 47. [CrossRef]

74. Zaccone, R.; Caruso, G.; Calì, C. Heterotrophic bacteria in the northern Adriatic Sea: Seasonal changes and ectoenzyme profile. Mar. Environ. Res. 2002, 54, 1-19. [CrossRef]

75. Obayashi, Y.; Suzuki, S. Occurrence of exo- and endopeptidases in dissolved and particulate fractions of coastal seawater. Aquat. Microb. Ecol. 2008, 50, 231-237. [CrossRef]

76. Zaccone, R.; Caruso, G. Microbial hydrolysis of polysaccharides and organic phosphates in the Northern Adriatic Sea. Chem. Ecol. 2002, 18, 85-94. [CrossRef]

77. Zaccone, R.; Caroppo, C.; La Ferla, R.; Zampino, D.; Caruso, G.; Leonardi, M.; Maimone, G.; Azzaro, M.; Sitran, R. Deep-chlorophyll maximum time series in the Augusta Gulf (Ionian Sea): Microbial community structures and functions. Chem. Ecol. 2004, 20 (Suppl. 1), 267-284. [CrossRef]

78. Mackey, K.R.M.; Labiosa, R.L.; Calhoun, M.; Street, J.H.; Post, A.F.; Paytan, A. Phosphorus availability, phytoplankton community dynamics, and taxon-specific phosphorus status in the Gulf of Aqaba, Red Sea. Limnol. Oceanogr. 2007, 52, 873-885. [CrossRef] 
79. Herut, B.; Krom, M.D.D.; Pan, G.; Mortimer, R. Atmospheric input of nitrogen and phosphorus to the Southeast Mediterranean: Sources, fluxes, and possible impact. Limnol. Oceanogr. 1999, 44, 1683-1692. [CrossRef]

80. Krom, M.D.; Herut, B.; Mantoura, R.F.C. Nutrient budget for the Eastern Mediterranean: Implications for phosphorus limitation. Limnol. Oceanogr. 2004, 49, 1582-1592. [CrossRef] 